\title{
O DEPÓSITO CRIOLITICO MACIÇO E O MINÉRIO DISSEMINADO DE CRIOLITA DA MINA PITINGA (AMAZONAS, BRASIL)
}

\author{
ORLANDO RENATO RIGON MINUZZI', ARTUR CEZAR BASTOS NETO², JUAN ANTONIO \\ ALTAMIRANO FLORES ${ }^{2}$, VITOR PAULO PEREIRA ${ }^{2} \&$ \\ JOSÉ TADEU MAXIMINO MIRAS FERRON ${ }^{1,3}$
}

\begin{abstract}
Resumo A mineralização de criolita está associada à fácies albita granito de núcleo do granito Madeira na mina (Sn, Nb e Ta) de Pitinga, na qual constituirá um novo co-produto. O albita granito é uma rocha de afinidade peralcalina, textura magmática, composição mineralógica semelhante à de um pegmatito, e que possui duas gerações de criolita disseminada, magmática $\mathrm{e}$ hidrotermal. A paragênese magmática é caracterizada por inversões na seqüência de cristalização relacionada ao magma muito rico em F. O depósito criolítico maciço (DCM), assemelha-se a um cogumelo lenticular instalado na zona apical, ao longo do eixo central vertical do albita granito. É formado por corpos sub-horizontais de criolita (extensão de até $300 \mathrm{~m}$ e espessura de até $30 \mathrm{~m}$ ) concentrados em duas Zonas Criolíticas, A e B, com $115 \mathrm{~m}$ e $150 \mathrm{~m}$ de espessura, respectivamente. São constituídos por criolita $(\sim 85 \%$ p. vol. $)+$ quartzo + zircão + k-feldspato + polilitionita \pm biotita \pm galena \pm gagarinita \pm xenotímio. No entorno do DCM aprofundam-se as curvas de isoteores do Nb e Ta. A zona do DCM foi o local preferencial para circulação de fluidos desde a consolidação do albita granito, tendo ocorrido processo de albitização e a formação da "auréola pegmatóide". A formação do DCM é atribuída a fluidos hidrotermais de baixa temperatura, residuais do albita granito, ascendentes de suas partes inferiores, que desestabilizaram os minerais de alta temperatura, gerando espaços para deposição de criolita. No entorno do DCM, os fluidos promoveram enriquecimentos no minério disseminado (columbitização do pirocloro e formação de criolita e zircão hidrotermais. A deposição da paragênese tardia (criolita branca e fluorita) é atribuída a uma diluição por fluidos meteóricos.
\end{abstract}

Palavras-chaves: mina Pitinga, criolita, albita granito, hidrotermal.

\begin{abstract}
MASSIVE AND DISSEMINATED CRYOLITE ORE IN THE PITINGA MINE (AMAZONAS STATE, BRAZIL). The cryolite deposit is associated to the albite granite facies of the Madeira granite. The albite granite has disseminated cryolite both magmatic and hydrothermal. The cryolite massive deposit (CMD) has a mushroom form and is located at the apical albite granite zone. It is composed by several sub-horizontal bodies with $300 \mathrm{~m}$ diameter and up to $30 \mathrm{~m}$ thick, distributed in two main cryolitic zones, A and B with, respectively, $115 \mathrm{~m}$ and $150 \mathrm{~m}$ thickness. The paragenesis is cryolite $(\sim 85 \%)+$ quartz + zircon $+\mathrm{k}$-feldspar + polylithionite \pm galena \pm xenotime. The CMD genesis is linked to low temperature residual hydrothermal solutions ascending from deeper parts of the albite granite. These solutions dissolved primary minerals, promoted cryolite deposition (CMD and disseminated ore) and pyrochlore columbitization at the albite granite. Subsequently, the hydrothermal system became convective and received meteoric water contribution; later white cryolite and fluorite depositions are related to this phase.
\end{abstract}

Keywords: Pitinga mine, cryolite, albite granite, hydrothermalism.

INTRODUÇ̃̃o A criolita é um aluminofluoreto de sódio $\left(\mathrm{Na}_{3} \mathrm{AlF}_{6}\right.$ ) composto idealmente (em peso) por $32,85 \% \mathrm{Na}$, $12,85 \% \mathrm{Al}$ e $54.30 \% \mathrm{~F}$ (Mineralogy Database 2005). O nome deriva do grego krios (gelo) e lithos (pedra), em referência ao brilho e ao índice de refração serem semelhantes aos do gelo. A criolita pura é incolor a branca. Os cristais com impurezas têm cor vermelha, marrom ou preta. A densidade varia entre 2,95 a $3,01 \mathrm{~g} / \mathrm{cm}^{3}$ e a dureza de 2,5 a 3 . O sistema de cristalização é monoclínico, com transição reversível para o sistema cúbico a $565^{\circ} \mathrm{C} \pm 5^{\circ} \mathrm{C}$. Sob aquecimento gradual produz luminescência amarela que desaparece em temperaturas mais elevadas. A fusão ocorre a $1000^{\circ} \mathrm{C}$ com expansão de volume de $41 \%$ (Pennsylvania Salt Manufaturing Company 1950). Até a revisão de Bailey (1980), eram conhecidas no mundo apenas 18 ocorrências de criolita. A jazida de Ivigtut (Groenlândia) foi a única explorada, desde o início do século passado até 1986. O depósito da Mina Pitinga (Fig. 1), única ocorrência confirmada no hemisfério sul, é o segundo caso com importância econômica.

A mina Pitinga é a maior produtora de cassiterita do Brasil. A cassiterita aluvionar, descoberta em 1978 (Veiga Jr. et al. 1979), é explorada desde 1980. O minério primário, associado à fácies albita granito do Granito Madeira, foi descoberto em 1983. A criolita disseminada nesta rocha foi identificada em 1986. Em 1989, sondagens revelaram a ocorrência de corpos de criolita maciça, subseqüentemente investigados por 57 furos que permitiram a definição do depósito criolítico maciço (DCM). Atualmente, a produção em Pitinga está voltada para o minério primário cuja exploração deverá em breve atingir o DCM. Neste distrito mineiro, também foram cubados depósitos de bauxita. A exploração da criolita, matéria prima fundamental na metalurgia do alumínio, é, portanto, estratégica para o distrito.

A jazida de $\mathrm{Sn}$ associada ao albita granito enquadra-se como um depósito de classe mundial, tendo $\mathrm{Nb}$, Ta e criolita como importantes co-produtos, e a possibilidade de Zr, ETR, Y, Li e U serem aproveitados como sub-produtos. Trata-se do primeiro caso mundial de minérios de $\mathrm{Sn}$ e $\mathrm{Nb}$ associados em rochas graníticas de classificação peralcalina.

A mineralização de criolita de Pitinga está sendo pela primeira vez estudada em detalhe, no quadro do projeto FINEP/ ADIMB/DNPM "Caracterização de depósitos minerais em distritos mineiros da Amazônia". Em função da originalidade da mineralização, julgou-se oportuno centralizar este trabalho nas 


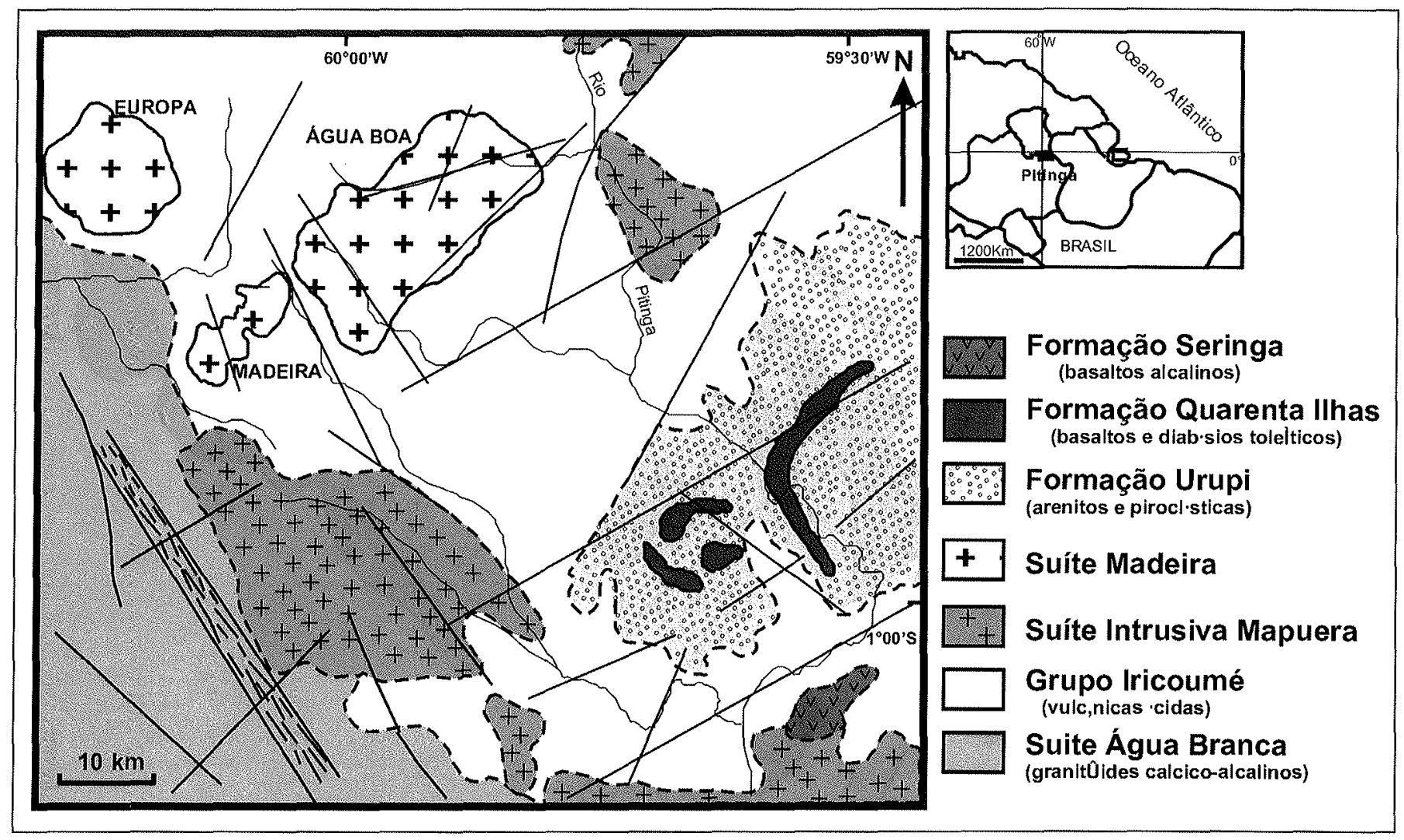

Figura I: Mapa geológico da região de Pitinga, adaptado de Costi (2000)

características básicas do depósito (morfologia, textura e paragênese do minério), comparando-as com a jazida de Ivigtut e efetuando uma revisão dos modelos genéticos propostos para a criolita de Pitinga.

METODOLOGIA No presente trabalho foi revisto e complementado o mapa geológico do albita granito de Costi (2000), assim como foram revisadas descrições de furos de sondagem e de lâminas delgadas. O estudo do DCM foi efetuado a partir de 21 dos 57 furos de sondagem que cortam o depósito e de alguns furos mais afastados para estudos comparativos. Adicionalmente, os furos na parte sudoeste da mina foram revistos para verificar a continuidade lateral da fácies granito hipersolvus e a mineradora executados 02 furos (locados pelos autores) na borda sul do albita granito para verificar as suas relaçôes de contato. No total, foram coletadas 337 amostras e descritas 62 lâminas delgadas.

No modelamento geológico do DCM e seu entorno, utilizouse os dados de descrição e análises químicas de testemunhos do programa de pesquisa do DCM (Minuzzi et al. 1990, 1991 e Minuzzi 1992, 1993, 2002), efetuado com uma malha base de $50 \mathrm{~m}$ x $50 \mathrm{~m}$, localmente adensada até $25 \mathrm{~m} \times 12,5 \mathrm{~m}$. Utilizouse o programa GEMCOM 4.11 que permitiu elaborar o modelo tridimensional do DCM e a provável cava da futura lavra a céu aberto. No total, foram analisados 1.780 intervalos para criolita, 1.090 intervalos para $\mathrm{Sn}, \mathrm{Zr}, \mathrm{Nb}, \mathrm{Y}, \mathrm{Ta}, \mathrm{Th}, \mathrm{U}$ e Rb, e codificados 14.833 intervalos geológicos, gerando-se 13 perfis verticais com espaçamento de $25 \mathrm{~m}$ a $50 \mathrm{~m}$ e 118 planos horizontais com espaçamento de $5 \mathrm{~m}$.

\section{TRABALHOS ANTERIORES}

Geologia regional A área da mina Pitinga (Fig. 1) localiza-se na porção sul do Escudo das Guianas (Almeida et al. e Gibbs \& Barron 1983). Faz parte da Província Amazônia Central de Tassinari et al. (1999) e da Província Tapajós-Parimã de Santos
(2000). As rochas mais antigas da região são biotita monzogranitos isótropos de granulação média, calci-alcalinos da Suíte Água Branca de idades Pb-Pb em zircão de $1960 \pm 20$ Ma e 1938 $\pm 37 \mathrm{Ma}$, que ocorrem na porção sudoeste (Almeida et al. 1997). O Grupo Iricoumé é representado por rochas vulcânicas e piroclásticas ácidas, de composições riolítica a quartzo-traquítica, raramente riodacítica, datadas por Costi et al. (2000) em $1888 \pm$ $3 \mathrm{Ma}\left({ }^{207} \mathrm{~Pb} /{ }^{206} \mathrm{~Pb}\right.$ em zircão). As rochas do Grupo Iricoumé são intrudidas (Figura 1) pelos corpos da Suíte Intrusiva Mapuera. O termo Mapuera foi utilizado por Veiga Jr. et al. (1979) para designar todos os granitóides genericamente considerados como anorogênicos de tipo A que ocorrem na parte sul do Escudo das Guianas. Segundo Faria et al. (2000), são rochas isótropas, de composição alcalina a sub-alcalina, enquadradas no campo dos granitos tardi-orogênicos de Batchelor \& Bowden (1985) e no domínio dos granitos intraplaca de Pearce et al. (1984). Costi (2000) incluiu na Suíte Madeira os corpos mineralizados Água Boa e Madeira (ver adiante). Veiga Jr. et al. (1979) descreveram na parte leste as unidades: (1) Formação Urupi (quartzo-arenitos e arcósios de ambiente continental, depositados em bacia isolada); (2) Formação Quarenta Ilhas (gabros); e (3) Formação Seringa (diques de rochas basálticas alcalinas, datados por Araújo Neto \& Moreira (1976) pelo método K-Ar em hornblenda em $1079 \pm 18 \mathrm{Ma})$.

Geologia local e mineralização O Granito Madeira (Fig. 2) abrange uma superfície de $60 \mathrm{~km}^{2}$. As denominações empregadas para as suas fácies são correlacionadas na Tabela 1. Costi et al. (2000) determinaram idades $\left({ }^{207} \mathrm{~Pb} /{ }^{206} \mathrm{~Pb}\right.$ em zircão) de 1824 $\pm 2 \mathrm{Ma}$ (anfibólio-biotita sienogranito), $1822 \pm 2 \mathrm{Ma}$ (biotitafeldspato alcalino granito) e $1818 \pm 2 \mathrm{Ma}$ (feldspato alcalino granito hipersolvus). Fuck et al. (1993) e Lenharo (1998) dataram o albita granito em $1834 \pm 6 \mathrm{Ma}(\mathrm{U}-\mathrm{Pb}$ em zircão) e $1794 \pm$ $19 \mathrm{Ma}\left({ }^{207} \mathrm{~Pb} / 206 \mathrm{~Pb}\right.$ em zircão por SHRIMP), respectivamente. 


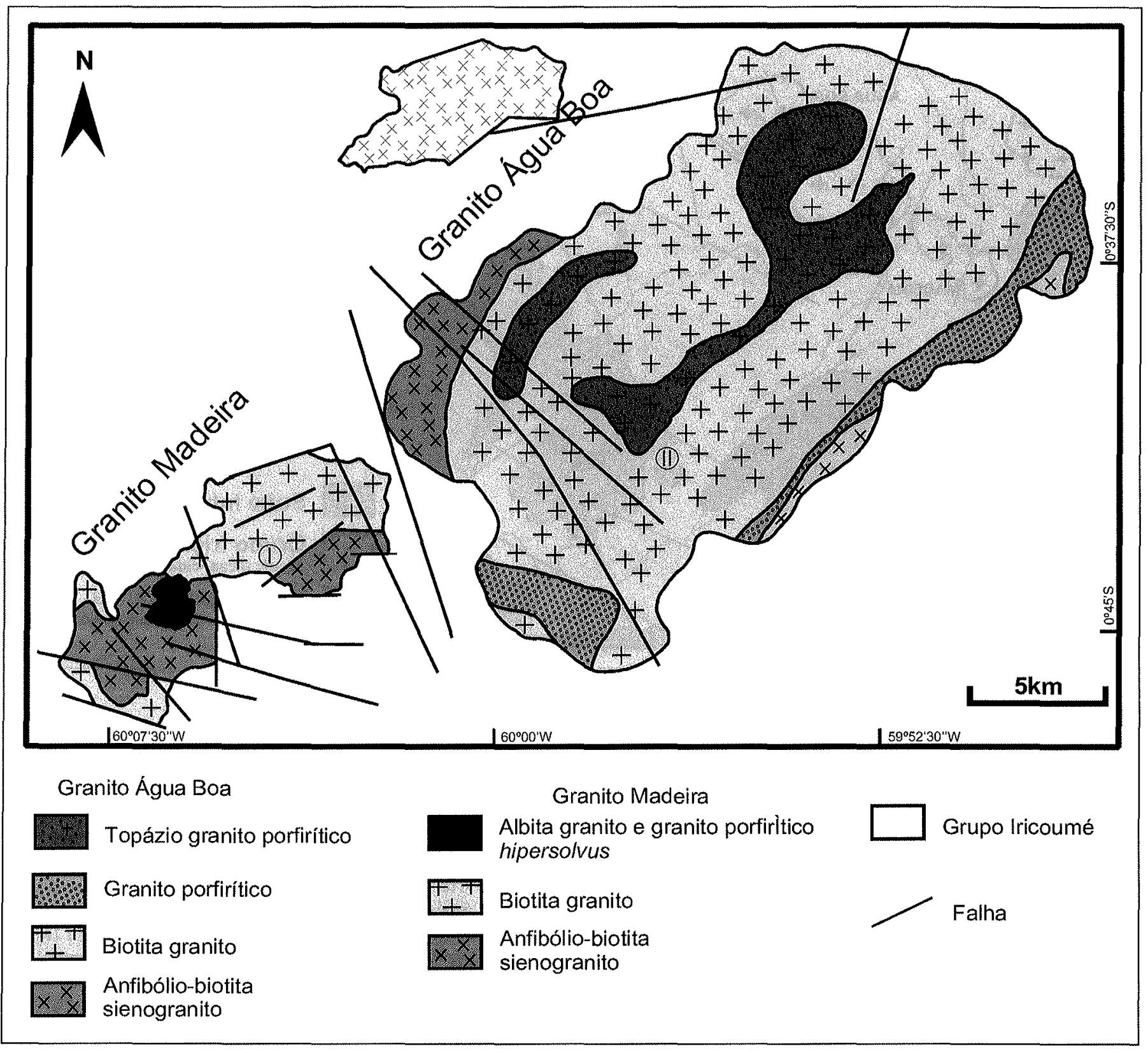

Figura 2: Mapa geológico da mina Pitinga, modificado de Costi (2000).

Tabela 1. Correlação das fácies do granito Madeira propostas por diversos autores.

\begin{tabular}{|c|c|c|l|}
\hline $\begin{array}{c}\text { HORBE } \text { et al. } \\
(1985,1991)\end{array}$ & MINUZZI (1995) & COSTI (2000) & MINUZZI (2004) \\
\hline Granito rapakivi & Granito rapakivi & Anfibólio-biotita-sienogranito & Anfibólio-biotita-sienogranito \\
\hline Biotita granito & Biotita granito & Biotita-feldspato alcalino granito & Biotita-feldspato alcalino granito \\
\hline $\begin{array}{c}\text { Granito alcalino } \\
\text { porfirítico }\end{array}$ & $\begin{array}{c}\text { Feldspato-alcalino granito } \\
\text { hipersolvus porfirítico }\end{array}$ & $\begin{array}{l}\text { Feldspato-alcalino granito } \\
\text { hipersolvus porfirítico }\end{array}$ \\
\hline $\begin{array}{c}\text { Apogranito de } \\
\text { núcleo }\end{array}$ & Apogranito de núcleo & Albita granito de núcleo (AGN) & Albita granito de núcleo (AGN) \\
\hline $\begin{array}{c}\text { Apogranito de } \\
\text { borda }\end{array}$ & Apogranito de borda & $\begin{array}{c}\text { Albita granito de borda (AGB) } \\
\text {-albita granito de borda }\end{array}$ & Albita granito de borda (AGB) \\
\hline
\end{tabular}


A fácies anfibólio-biotita-sienogranito é a mais precoce e em suas bordas ocorrem enclaves de rochas do Grupo Iricoumé. A textura é equigranular a porfirítica, com intercrescimentos micrográficos na matriz dos tipos porfiríticos, assim como intercrescimentos simplectíticos entre biotita e anfibólio que sugerem cristalização em nível crustal raso. A rocha é metaluminosa, constituída de feldspato alcalino pertítico, quartzo e plagioclásio, tendo como acessórios, biotita, hornblenda, zircão, fluorita e opacos.
A fácies biotita-feldspato alcalino granito é intrusiva na anterior. É peraluminosa, sua textura é equigranular, localmente porfirítica, constituída por feldspato alcalino pertítico e quartzo, pouco plagioclásio, biotita em volume de varietal, enquanto fluorita, zircão, opacos e topázio são fases acessórias. A fácies feldspato alcalino granito hipersolvus porfirítico tem textura porfirítica com matriz de granulação fina a média, é constituída por feldspato alcalino e quartzo, enquanto o plagioclásio é

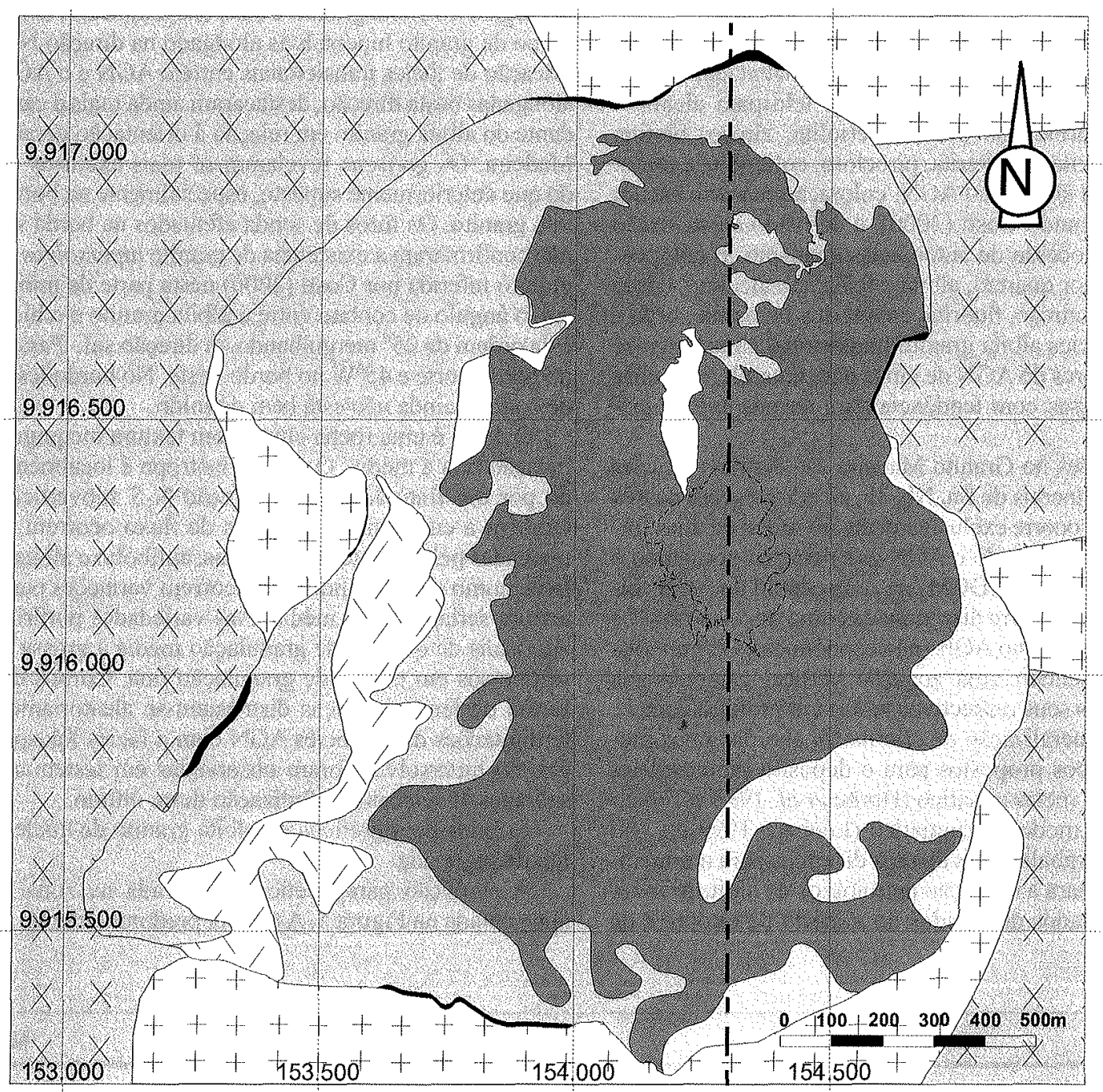

Greisen

Albita granito de borda (AGB)

Albita granito transicional (AGT)

Albita granito de núcleo (AGN)
Feldspato alcalino granito hipersolvus porfirítico $(\mathrm{GH})$

Biotita-feldspato alcalino granito $(B G)$

Anfibólio-biotita sienogranito (RK)

Projeção do Depósito Criolítico Maciço em superfície

- Perfil geológico da serra do Madeira

Figura 3: Mapa geológico da fácies albita granito do granito Madeira. 
representado pela albita tardia que ocorre como pertitas nos indivíduos de feldspato alcalino. Biotita, fluorita, zircão e opacos ocorrem como acessórios. Nesta fácies, são difundidas as feições de transformações metassomáticas sob a forma de albitização e epi-sienitização do feldspato alcalino granito hipersolvus. O contato com a fácies albita granito é transicional.

A fácies albita granito (Fig. 2 e 3 ) tem uma área de ocorrência alongada na direção N-S, contrastando com a direção NE$\mathrm{SW}$ do granito Madeira. É intrusiva nas fácies anteriores, com formação de pegmatitos e greisens nos bordos norte, noroeste, sul e sudoeste, respectivamente. Divide-se nas sub-fácies albita granito de núcleo (AGN) e albita granito de borda (AGB).

$\mathrm{O} A \mathrm{ANN}$ é um granito subsolvus, de textura porfirítica a seriada, granulação fina a média, coloração acinzentada, constituído essencialmente por quartzo, albita e feldspato alcalino. Como acessórios principais ocorrem criolita, zircão, biotita, polilitionita, riebeckita, cassiterita, pirocloro, columbita e torita. $\mathrm{O}$ AGB tem textura similar ao AGN, coloração marrom escura a avermelhada. Segundo Costi (2000), é derivado da oxidação do AGN por um processo de autometassomatismo. É composto essencialmente por quartzo, albita e feldspato alcalino, como acessórios ocorrem zircão, fluorita, cassiterita, hematita, torita e columbita. A subfácies albita granito transicional caracteriza-se pela mudança de cores do AGN de cinza para amarelo, manchas avermelhadas esparsas com tendência para termos avermelhados dominantes.

As mineralizações no Granito Madeira são restritas à fácies albita granito. Os minerais de $\mathrm{Sn}, \mathrm{Nb}, \mathrm{Ta}, \mathrm{Zr}$ e Y ocorrem na três subfácies. A criolita ocorre exclusivamente no AGN, de duas formas: (a) disseminada em todo o AGN e (b) maciça, formando o Depósito Criolítico Maciço (DCM) na zona central do AGN (Figuras 3 e 4). A fluorita ocorre disseminada como traços no AGT e com maior concentração no AGB (não econômica). Os minérios disseminados apresentam uma zonação vertical caracterizada pelo decréscimo dos seus respectivos teores em profundidade.

A gênese da mineralização de criolita foi abordada nos modelos metalogenéticos propostos para o depósito polimetálico. Estes são o modelo metassomático (Horbe et al. 1985 e Teixeira et al. 1991) e o modelo magmático (Lenharo 1999 e Costi 2000). Trata-se de trabalhos detalhados dirigidos para a mineralização de Sn e/ou para a evolução petrológica do albita granito, não apresentando dados detalhados do minério de criolita e da encaixante imediatamente adjacente ao DCM.

As reservas de $\mathrm{Sn}, \mathrm{Nb}$ e Ta do albita granito são de 164 milhões de toneladas (medida), com teores médios de $0,14 \%$ de $\mathrm{Sn}, 0,20 \%$ de $\mathrm{Nb}_{2} \mathrm{O}_{5}$ e $0,024 \%$ de $\mathrm{Ta}_{2} \mathrm{O}_{5}$, cubados até a cota $0 \mathrm{~m}$ (Pires et al. 1998). As reservas de criolita do DCM (Tabela 2) foram calculadas até a base da Zona Criolítica B (cota $-162 \mathrm{~m}$ ) (Teixeira et al. 1992).

RESULTADOS As novas informações obtidas por mapeamento de superfície (Fig. 3) e descrição de testemunhos de sondagem recente modificaram de forma significativa o mapa geológico do albita granito e suas encaixantes. A delimitação do corpo de granito hipersolvus alongado na direção N-S e a identificação de fácies transicionais entre o $A G N$ e o AGB, também alongadas nesta direção, destacaram ainda mais o caráter discordante do albita granito em relação à orientação geral do Granito Madeira. Os greisens revelaram-se mais extensos e contínuos do que anteriormente suposto, especialmente na borda sul do albita granito. Os furos de sonda efetuados na borda sul do corpo não confirmaram a existência de granito hipersolvus sob o albita granito inferida por Costi (2000) nesta parte da mina. Na borda sul, o ângulo de contato entre o albita granito e o biotita granito é da ordem de $25^{\circ}$ mergulhando na direção sul. Passa para $38^{\circ} \mathrm{N}$ no bordo norte e $45^{\circ} \mathrm{W}$ no bordo oeste. No bordo leste, o ângulo de contato ainda não está bem definido.

O AGN é uma rocha cinza, com textura inequigranular, granulação fina a média. O caráter isótropo é localmente mascarado por um fraturamento de direção N-S subvertical que afeta também a encaixantes. Texturas de fluxo ocorrem localmente, marcadas pela orientação de micas, anfibólio e albita. Em superfície, como em profundidade, ocorrem variações para rochas de textura seriada fina a média. Nas variedades porfiríticas, os fenocristais de quartzo de granulação média a grossa encontramse imersos em matriz de granulação fina. Corpos de albita em forma de lentes maciças distribuem-se aleatoriamente. As interdigitações da subfácies AGN com a fácies feldspato alcalino granito hipersolvus foram observadas em testemunhos, sendo salientes as feições de albitização deste último.

Estudos petrográficos do albita granito de núcleo com criolita disseminada

A evolução paragenética encontrada na zona do DCM é apresentada na Figura 5. A textura predominante no AGN é por-

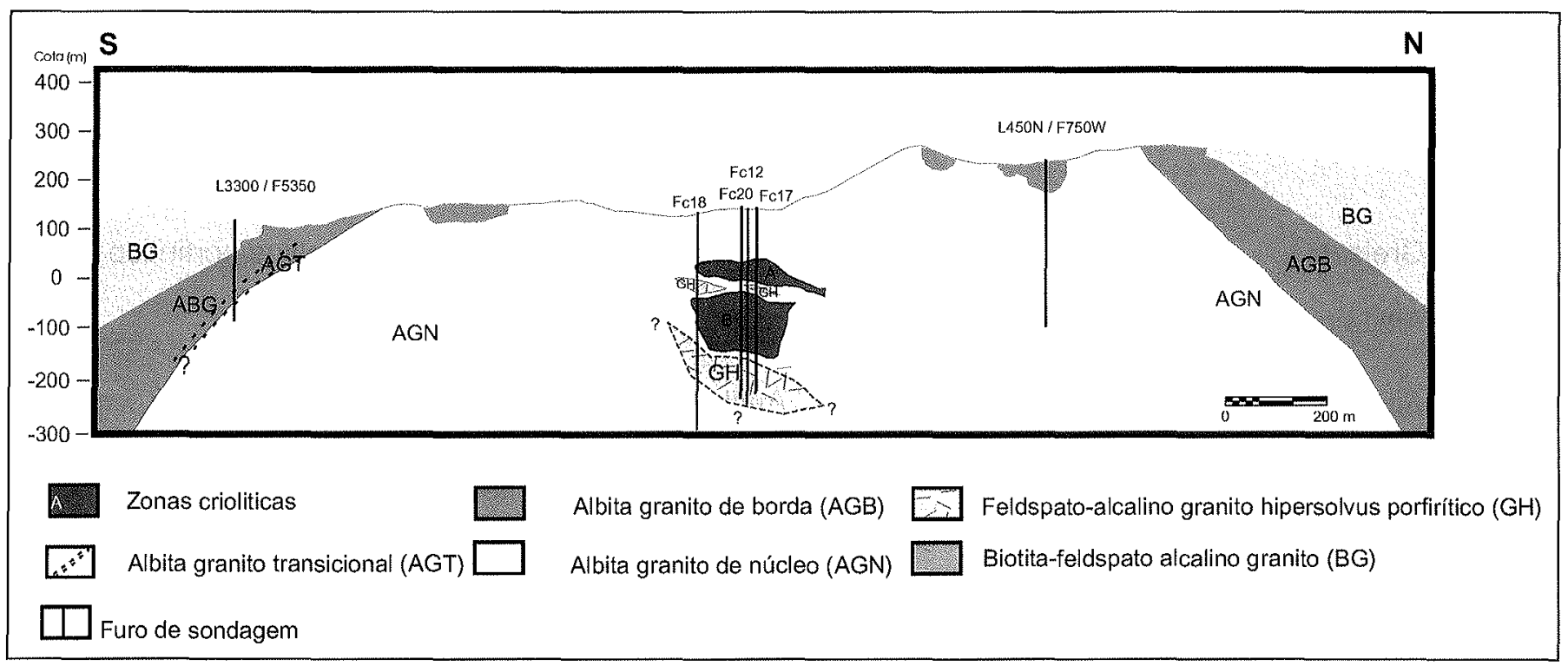

Figura 4: Perfil geológico do albita granito e encaixantes na serra do Madeira (mina Pitinga). 


\begin{tabular}{|ccccc|}
\hline & \multicolumn{4}{c|}{ Depósito Criolítico Maciço } \\
Reserva & Zona & ROM $(\mathrm{t})$ & Teor $\%\left(\mathrm{Na}_{3} \mathrm{AlF}_{6}\right)$ & Criolita $(\mathrm{t})$ \\
Medida & A & 2.501 .786 & 34,4 & 861.319 \\
Medida & $\mathrm{B}$ & 7.469 .138 & 31,0 & 2.315 .726 \\
Total & & 9.970 .924 & 31,9 & 3.177 .045 \\
\hline
\end{tabular}

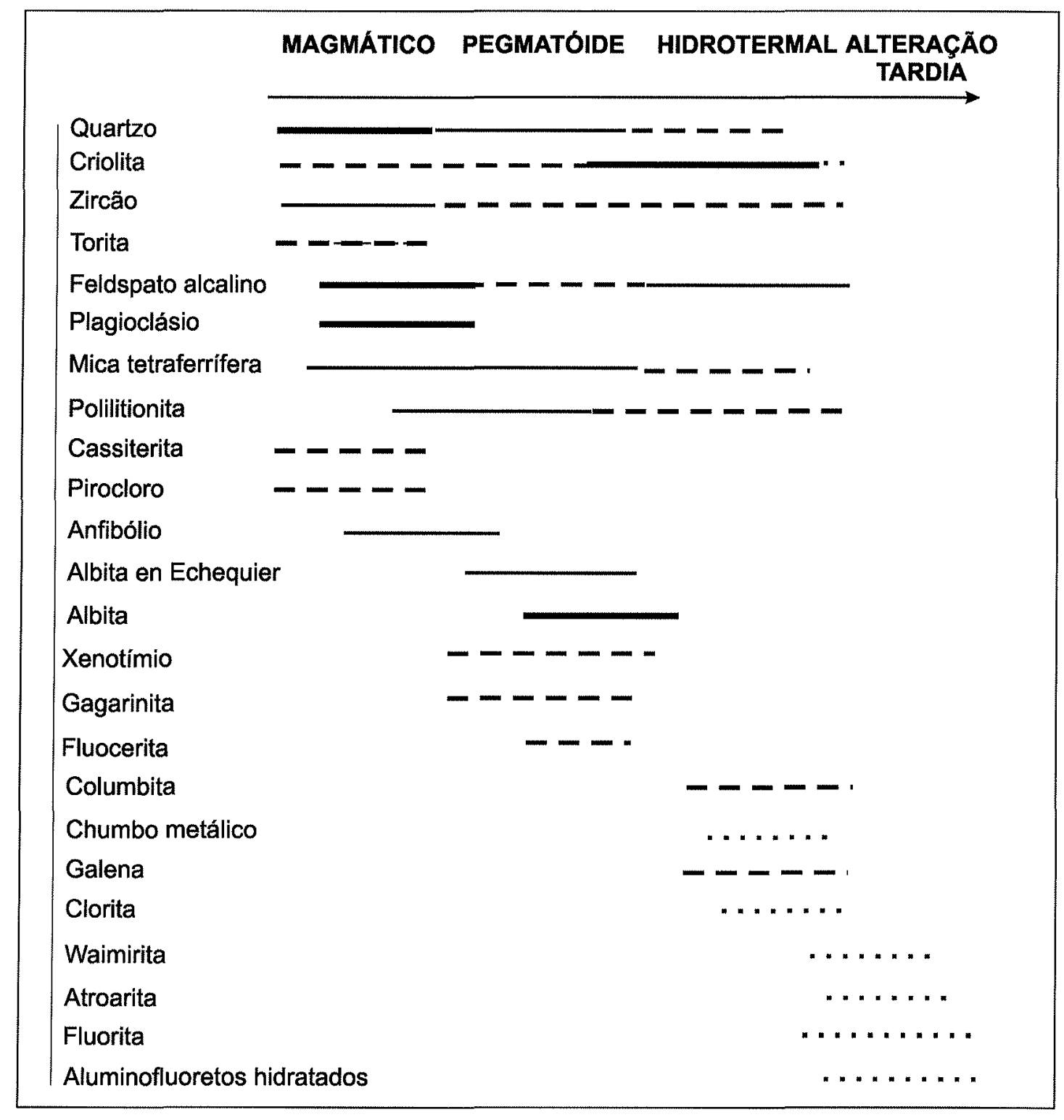

Figura 5: Evolução paragenética na zona do Depósito Criolítico Maciço (albita granito encaixante, auréola pegmatóide e corpos de criolita maciça)

firítica, também ocorre textura seriada e transição entre ambas. Os fenocristais de quartzo e ortoclásio e/ou microclínio (pertítico) são arredondados a subarredondados. A matriz é constituída por albita, albita en échiquier, quartzo, ortoclásio e/ou microclínio, micas, anfibólio, zircão, cassiterita, criolita, pirocloro e columbita. O quartzo, a albita e o feldspato potássico ocorrem em proporções semelhantes da ordem de $30 \%$ (p. vol.), são seguidos em abundância pela criolita (4\%) e zircão (1\%).
O quartzo ocorre como fenocristais e na matriz. Em ambos os casos, os cristais são anédricos, podem ser incolores e límpidos (Fig. 6A) ou conter numerosas inclusões. As dimensões variam entre $0,30 \mathrm{~mm}$ a $3,70 \mathrm{~mm}$ (fenocristais) e 0,07 a $0,15 \mathrm{~mm}$ (matriz). Os contatos com o zircão (não metamictizado) são retilíneos (Fig. 6B), assim como com biotita (Fig. 6C), feldspato potássico (Fig. 6D), pirocloro, columbita e cassiterita. Uma feição textural significativa é a corrosão dos fenocristais pela 
albita e criolita da matriz (Fig. 6E). O contato com mica branca é irregular, porém, sem corrosão. Os fenocristais de quartzo contêm inclusões principalmente de albita e criolita (Fig. 6F), subordinadamente zircão e, raramente, pirocloro. Em alguns
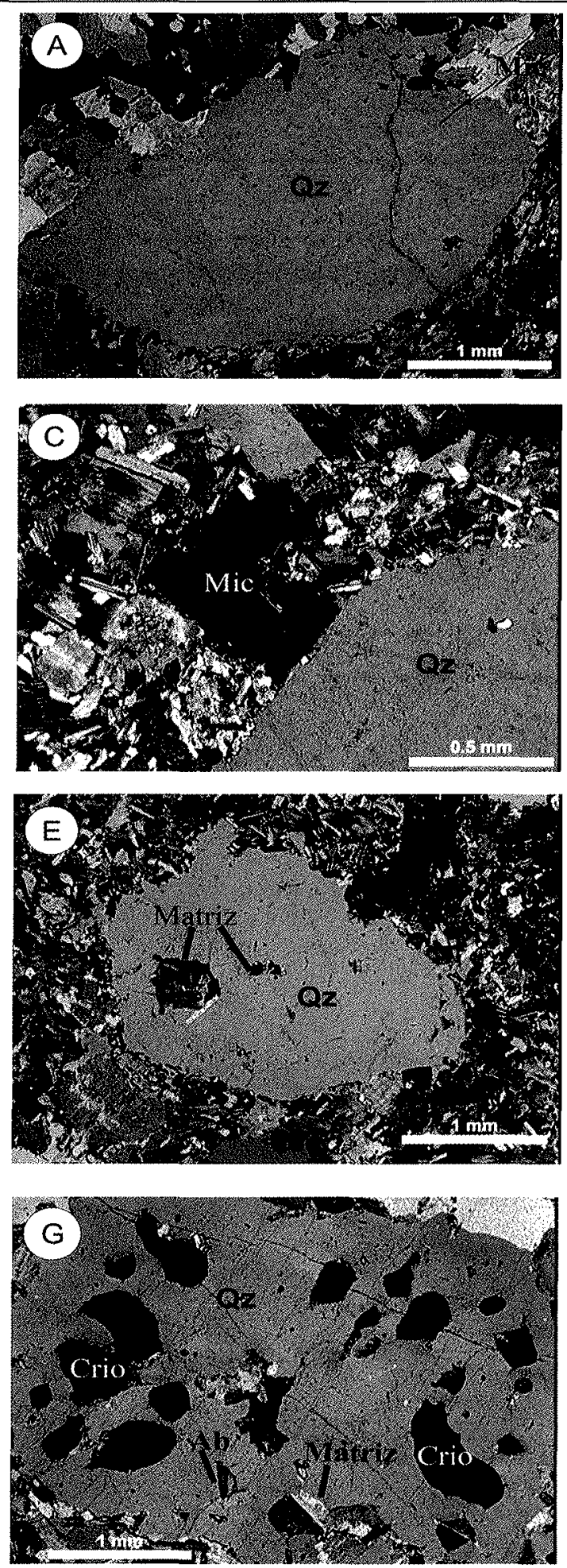
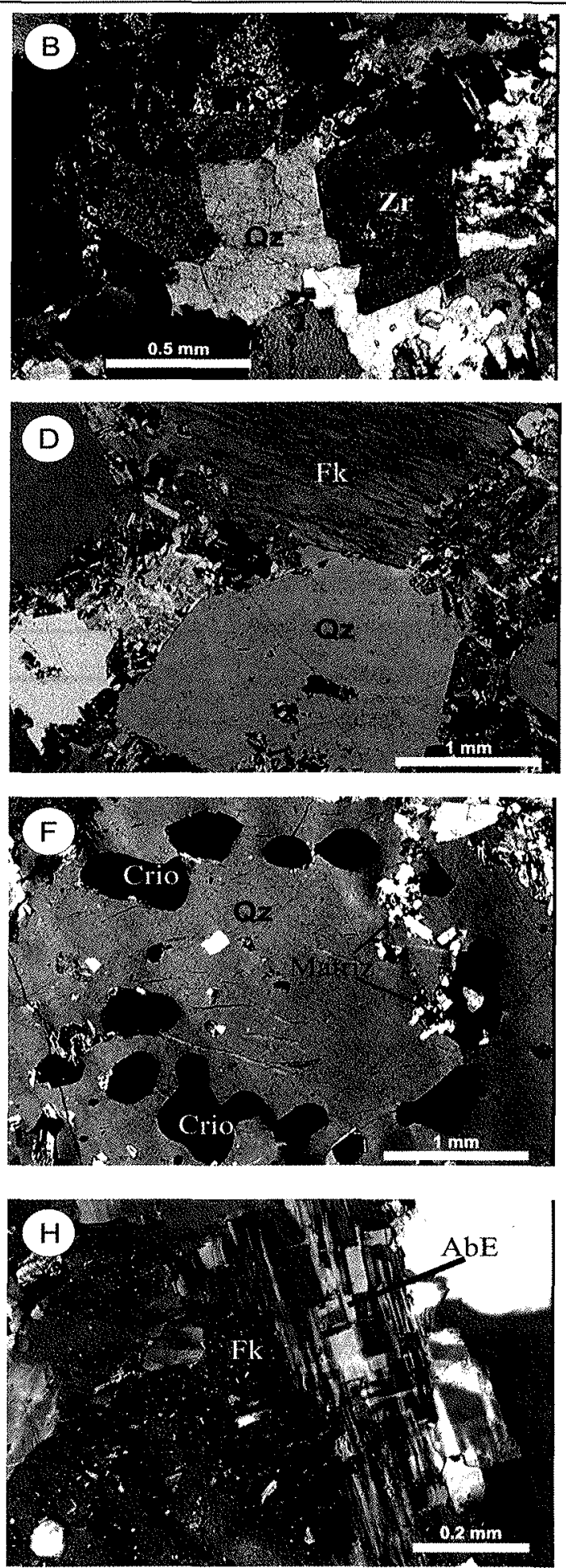

Figura 6: Fotomicrografias do albita granito de núcleo na zona do Depósito Criolítico Maciço: (A) Fenocristal de quartzo límpido com as bordas corroidas pela matriz; (B) Cristal de quartzo em contato retilineo com cristais de zircão (não metamíctico); (C) Cristais de quartzo em contato retilíneo com biotita; (D) Contato em equilibrio do feldspato alcalino com o quatzo, bordas do quartzo corroidas pela matriz albiticalcriolitica; (E) Fenocristal de quartzo com bordas corroidas; (F) Fenocristal de quartzo contendo inclusões concêntricas de criolita e vênula preenchida por material da matriz formando pseudo-inclusões; (G) Fenocristal de quartzo com inclusões de criolita e albita possivelmente associadas a microfissuras; (H) Albita en échiquier formada na borda do feldspato alcalino. Abreviaturas: (Qz) quartzo, (AbE) albita en échiquier, (Crio) criolita, (Fk) feldspato alcalino, (Mic) mica, (Zr)zircão. 
casos, os minerais inclusos parecem estar associados a microfissuras lineares (Fig. 6G) ou, mais raramente, fraturas curvilíneas ás quais associam-se em conjunto ou individualmente. Os contatos entre quartzo da matriz e albita da matriz são retilíneos a irregulares sem evidência de reação.

O feldspato alcalino ocorre como fenocristais de ortoclásio e/ou microclínio (Fig. 6D), geralmente turvos, com dimensões médias em torno de $4 \mathrm{~mm}$, podendo atingir 7,60 mm. A pertitização é uma feição difundida, que se acentua em profundidade com desenvolvimento de termos mais albitizados. Os contatos entre os fenocristais de quartzo e feldspato alcalino são retilíneos, enquanto com a matriz albítica é reativo. Evidências de albitização são freqủentes, como, por exemplo, a formação de albita en échiquier (Fig. $6 \mathrm{H}$ ) em cristais de até 1,0 mm.

A albita ocorre sob três formas texturais, correspondendo, provavelmente, a três gerações distintas. A primeira, mais precoce e mais abundante, encontra-se preferencialmente na matriz da rocha como cristais euédricos a subédricos, límpidos, com geminação segundo a lei da albita (Fig. 7D), dimensões entre $0,04 \mathrm{~mm}$ a $0,481 \mathrm{~mm}$ e contatos reativos com a criolita. Mais raramente, a albita ocorre como inclusão ou na borda de feldspato alcalino. $\mathrm{O}$ segundo tipo de albita tem macla en échiquier, ocorre como cristais de até $3,70 \mathrm{~mm}$, formados, principalmente, em substituição ao feldspato alcalino (Fig. 6H). Na matriz, ocorre na forma de indivíduos com dimensões de $0,27 \mathrm{~mm}$ a $1,03 \mathrm{~mm}$, maiores do que a albita mais precoce (Fig. 7E). No contato com a biotita, desenvolvem-se finos cristais de mica branca (Fig. 7F). O terceiro tipo de albita, provavelmente mais tardio, é representado por cristais com maclas difusas que ocorrem na matriz (Fig. $7 \mathrm{G})$ ou como cristais diminutos $(0,08 \mathrm{~mm}$ a $0,15 \mathrm{~mm})$ sobre a albita en échiquier.

A criolita disseminada pertence a pelo menos duas gerações, todas com baixo índice de refração, quase isótropas e raramente apresentando maclas. A criolita precoce ocorre mais freqüentemente como cristais $(0,02 \mathrm{~mm}$ a $1,05 \mathrm{~mm})$ com formas subédricas a anédricas (freqüentemente arredondados) disseminados na matriz das rochas porfiríticas, freqüentemente associada com o zircão precoce com o qual encontra-se em equilíbrio (Fig. $7 \mathrm{G}$ ). Também ocorre comumente como inclusões ovóides $(0,037 \mathrm{~mm}$ a $0,30 \mathrm{~mm}$ ) em fenocristais de quartzo, também sem feições de corrosão com este mineral (Fig. 6G). A criolita forma agregados irregulares a arredondados de granulação média a grossa, aos quais se juntam zircão, cassiterita, torita, micas da família polilitionita, opacos e, ocasionalmente, riebeckita. Estes aglomerados, considerados de formação tardia por Costi (2000), podem ser distinguidos em amostras de mão pela tonalidade escura e dimensões até centimétricas. Nas amostras do AGN da zona do DCM, a criolita é mais abundante; três formas são típicas desta zona: (1) envolvendo totalmente ou parcialmente cristais de zircão magmático e de pirocloro (Fig. $7 \mathrm{H}, 8 \mathrm{~A} \mathrm{e} 8 \mathrm{H}$ ), apresentando coroas de reação com ambos (e também com a cassiterita), (2) formando aglomerados com mica (Fig. 8D) e/ou zircão (Fig. $8 \mathrm{C}$ ), freqüentemente associados a fissuras e (3) finamente disseminada na matriz da rocha. Os cristais de criolita (de todos os tipos acima) podem apresentar microfissuras preenchidas por minerais possivelmente relacionados à sua alteração, tentativamente identificados como thonsenolita e prosopita.

$\mathrm{O}$ zircão precoce é esqueletal (Fig. 7A), ocorre principalmente incluso em outros minerais, sem desenvolver auréolas metamícticas, com freqüentes concentrações de óxido de ferro nas bordas e dimensões em torno de $0,04 \mathrm{~mm}$. Uma segunda geração de zircão ocorre como cristais euédricos a subédricos (entre $0,14 \mathrm{~mm}$ e $1,55 \mathrm{~mm}$ ) individuais ou formando os agregados acima descritos (com cassiterita, torita, mica, criolita, riebeckita e opacos) ou como cristais. O zircão considerado mais tardio também forma cristais euédricos e bem desenvolvidos, mas ocorre mais tipicamente associado com mica branca e criolita e não apresenta bordas reativas com esta geração de criolita.

O pirocloro ocorre como grãos de dimensões variáveis entre $0,07 \mathrm{~mm}$ e $0,41 \mathrm{~mm}$, subédricos a euédricos, marrom a amarelo. É disseminado de forma intersticial aos cristais de albita e aos demais minerais acessórios (cassiterita, zircão, micas e anfibólio). Também ocorre incluso em quartzo e, eventualmente, em feldspatos. $O$ contato com a albita e a criolita freqüentemente é marcado por bordas reativas, especialmente com este último mineral (Fig. 7H, 8A, 8E). Os contatos com zircão e quartzo são retilíneos, límpidos e não reativos. O pirocloro apresenta variações composicionais (Fig. $8 \mathrm{E}$ ) ligadas a um processo de alteração (columbitização). A partir do pirocloro primário (U$\mathrm{Pb}$ pirocloro), forman-se sucessivamente $\mathrm{Pb}-\mathrm{U}$ pirocloro, $\mathrm{U}$ pirocloro e columbita (Minuzzi 2004). Associadas à alteração do pirocloro, formaram-se inclusões de chumbo metálico e uma auréola rica em ferro.

A columbita (Fig. 8F) encontrada na encaixante próxima ao DCM resulta da alteração do pirocloro. Seus cristais possuem formas e dimensões semelhantes às do pirocloro original, podendo conter relictos deste em quantidades variáveis. A cassiterita ocorre principalmente como cristais de $0,08 \mathrm{~mm}$ a $0,62 \mathrm{~mm}$, associados à matriz (Fig. $8 \mathrm{G}$ ), geralmente subédricos a euédri$\cos$, com coloração castanho avermelhado, por vezes contendo inclusões do zircão primário. Também forma aglomerados com mica e zircão e riebeckita. Os cristais podem ser zonados (Fig. 9A). Os contatos com a criolita e a albita são caracterizados por feições de corrosão por estes minerais (Fig. 9B). Apesar da corrosão, em alguns casos, percebe-se a forma original dos cristais maiores de cassiterita (Fig. 9C).

A riebeckita forma cristais prismáticos $(\sim 0,10 \mathrm{~mm})$, em alguns casos fibrosos, o contato é retilíneo com o quartzo da matriz e irregular com a albita. Localmente engloba feldspatos, criolita, zircão, pirocloro/columbita e opacos sugerindo uma cristalização tardia. A mica branca ocorre como cristais individuais de $0,074 \mathrm{~mm}$ a $2,73 \mathrm{~mm}$ ou em agregados com zircão e criolita (Fig. 9D). A clivagem é destacada pela presença de óxidos de ferro. Outra variedade textural de mica branca é representada por cristais de $0,039 \mathrm{~mm}$ a $0,11 \mathrm{~mm}$, associados à alteração da biotita e do feldspato alcalino. A biotita ocorre na matriz (Fig. 9E) como cristais subédricos de $0,60 \mathrm{~mm}$ a $0,30 \mathrm{~mm}$, ou forma agregados de cristais com dimensões de $0,15 \mathrm{~mm}$ a $2,22 \mathrm{~mm}$. Também ocorre em vênulas que cortam indistintamente a rocha (Fig. 9F). Tem coloração marrom alaranjado a esverdeado, pleocroísmo forte a médio, e sua clivagem é destacada por hidróxidos de ferro.

A torita é geralmente opaca, com tamanho de $0,05 \mathrm{~mm}$ a $0,37 \mathrm{~mm}$, intersticial na matriz e com auréola reativa em relação aos minerais vizinhos. Em fissuras radiais a partir da torita ocorrem minerais opacos. A waimirita (Fig. 9G) e a atroarita (Fig. 9H) são dois minerais novos (Minuzzi et al. 2003), ainda em estudo, que ocorrem em vênulas milimétricas cortando indistintamente o AGN.

\section{DEPÓSITO CRIOLÍTICO MACIÇO}

Características gerais O DCM é formado por um conjunto de corpos de criolita maciça, que ocorrem desde a cota $(+) 78$ $\mathrm{m}$ até a cota (-)163 m, concentrados em duas zonas principais: Zona Criolítica A (ZCA), entre as cotas $(+) 78 \mathrm{~m} \mathrm{e}(-) 36 \mathrm{~m}$, e Zona Criolítica B (ZCB), entre as cotas (-)10 m e (-)163 m (Fig. 4). Entre as cotas $(+) 82 \mathrm{~m} \mathrm{e}(+) 55 \mathrm{~m}$ ocorrem corpos esparsos que podem representar uma terceira zona, quase totalmente erodida, denominada Zona Criolítica Zero.

Nos testemunhos de sondagem (vertical), os ângulos de contato entre os corpos de criolita e a encaixante são variados, permitindo supor a presença de corpos desde horizontais até forte- 

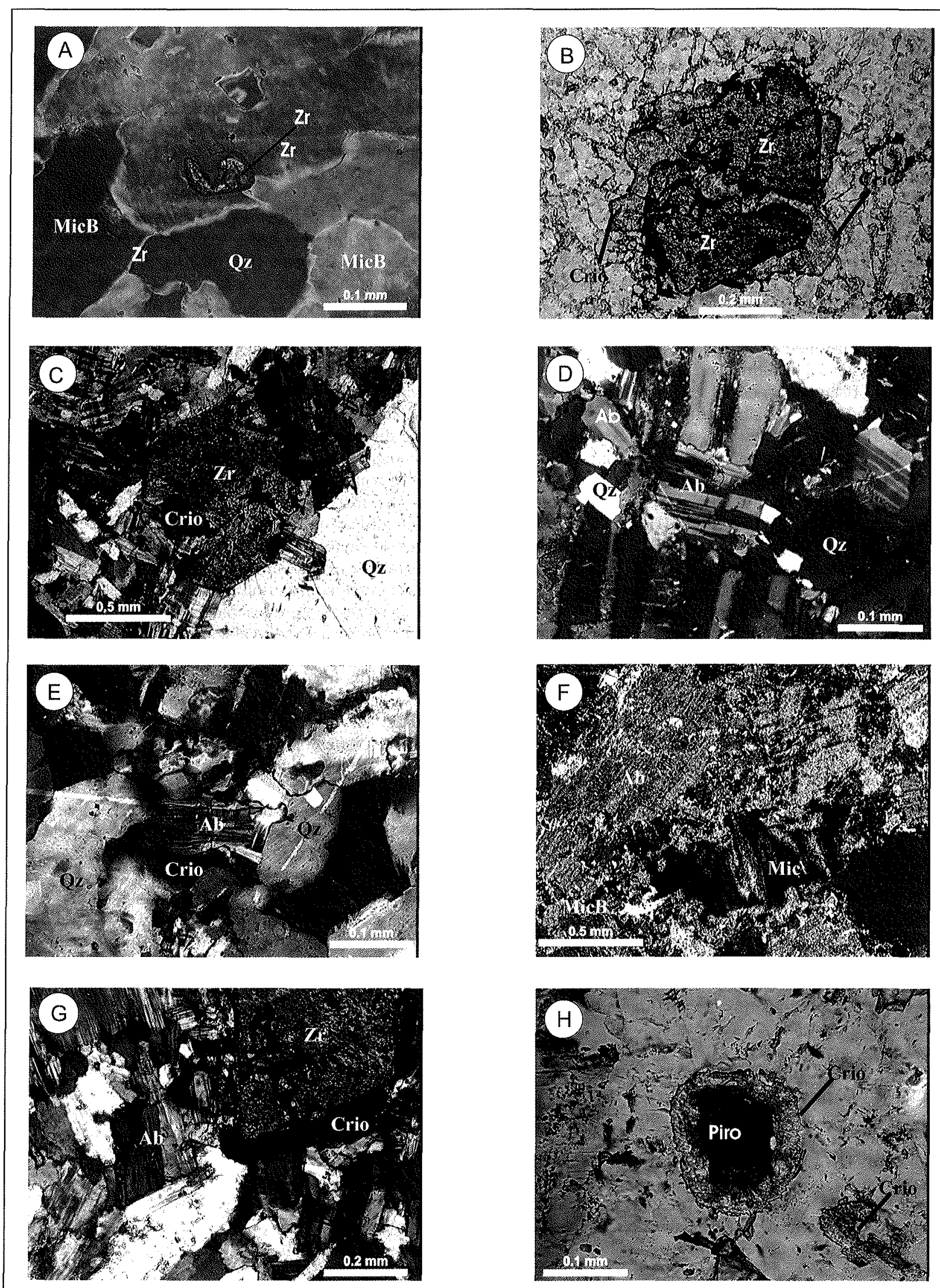

Figura 7: Fotomicrografias do albita granito de núcleo na zona do depósito criolitico maciço. (A) Zircão precoce, não metamictico, associado a agregado de mica branca; (B) Zircão com feições de corrosão pela criolita; (C) Zircão tardio em contato retilíneo com quartzo; (D) Albita da matriz com maclamento difuso; (E) Albita da matriz com maclas difusas e contatos reentrantes com a criolita; $(F)$ Albita e biotita da matriz com formação de mica branca no contato; (G) Criolita em equilibrio com zircão que é corroído pela albita da matriz; (H) Auréola de criolita com borda de reação com o pirocloro. Abreviaturas: $(Q z)$ quartzo, (Zr) zircão, (Piro) pirocloro, (Ab) albita, (Crio) criolita, (Mic) mica, (MicB) mica branca. 

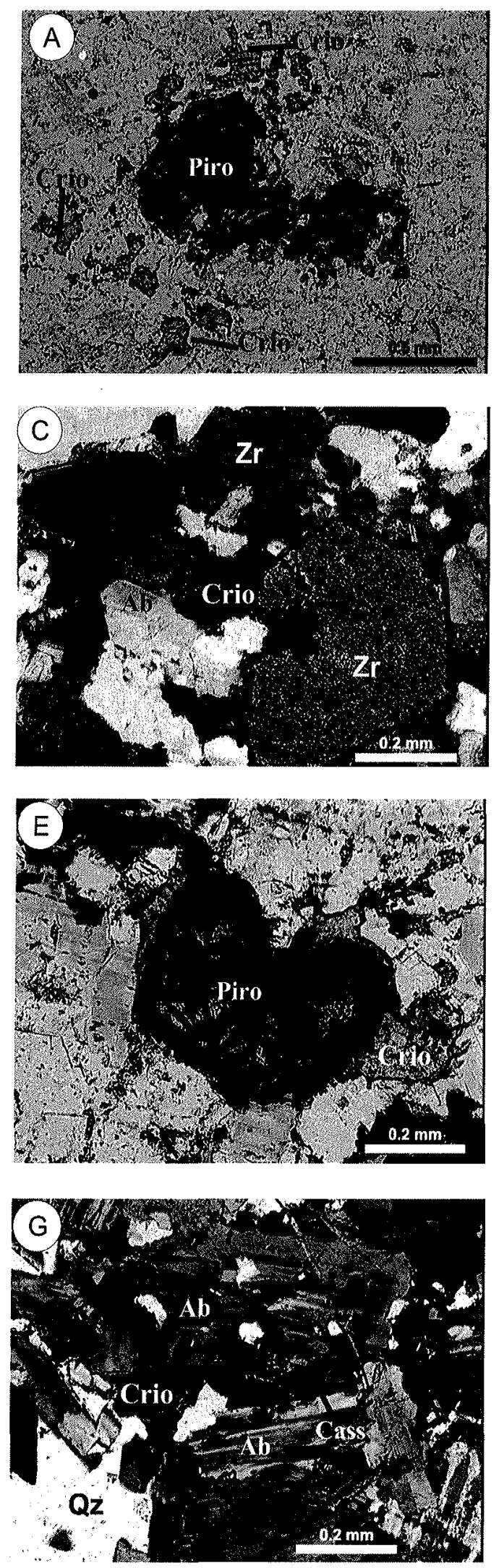
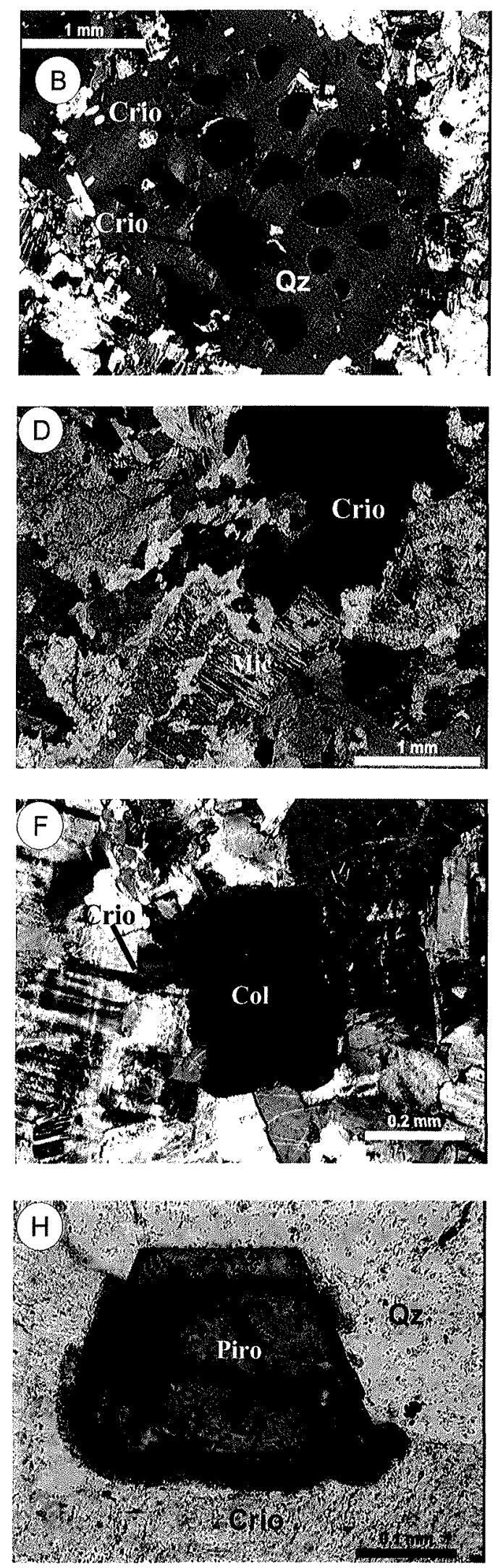

Figura 8: Fotomicrografias do albita granito de núcleo na zona do Depósito Criolítico Maciço. (A) Pirocloro corroido por criolita; (B) Fenocristal de quartzo com inclusões ovóides de criolita, albita e matriz; (C) Agregados de zircão e criolita com bordas reativas entre estes minerais; (D) Agregados de criolita e mica interdigitados; (E) Cristal de pirocloro em processo de columbitização, zonas claras (U-Pb pirocloro), zonas escuras ( $\mathrm{Pb}$-U pirocloro); $(F)$ Columbita formada por alteração do pirocloro, com borda de óxido de ferro resultante da alteração; $(G)$ Cassiterita disseminada na matriz; $(H)$ U-Pb pirocloro em contato retilíneo com o quartzo e reativo com a criolita. Abreviaturas: (Qz) quartzo, (Zr) zircão, (Piro) pirocloro, (Col) Columbita, (Ab) albita, (Crio) criolita, (Mic) mica, (Fk) feldspato alcalino. 

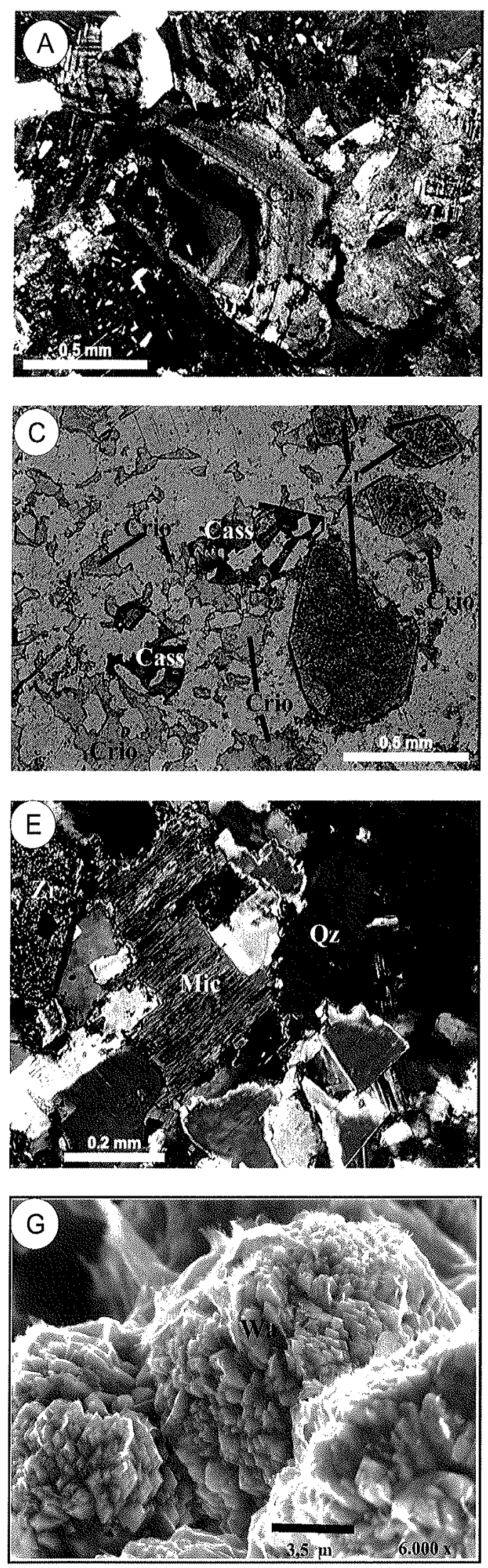
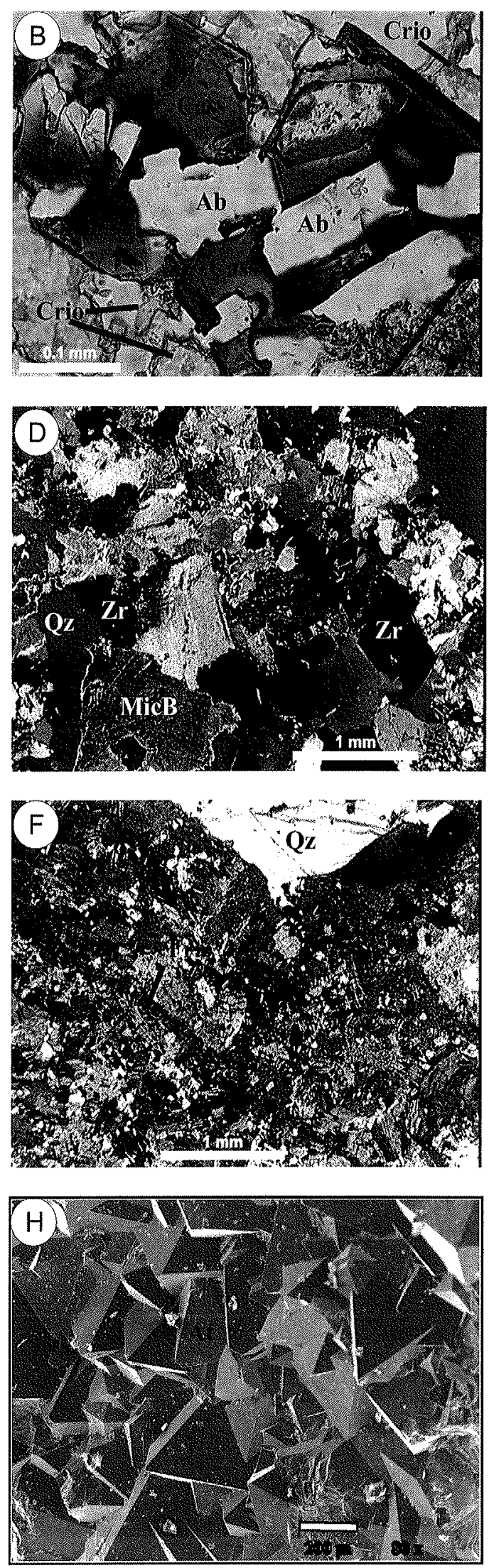

Figura 9: Fotomicrografias e imagens obtidas por microscópio eletrônico de varredura (MEV) do albita granito de núcleo na zona do depósito criolítico maciço. (A): Cassiterita zonada; (B) Cassiterita corroída por criolita e albita, ; (C) Cassiterita e zircão corroídos por albita e criolita; (D) Agregado de mica branca, zircão e criolita; (E) Biotita, quartzo e albita da matriz; (F) Vênula de biotita; ( $G$ ) Imagem $M E V$ de cristais de waimirita em forma de roseta; (H) Imagem $M E V$ de cristais octaédricos de atroarita. Abreviaturas: ( $\mathrm{Qz}$ ) quartzo, $(\mathrm{Zr})$ zircão, (Cass) cassiterita, (MicB) mica branca, (Ab) albita, (Crio) criolita, (At) Atroarita, (W) waimirita, (Fra) fratura. 
mente inclinados. As correlações laterais entre os diversos furos sugerem, entretanto, tratar-se predominantemente de corpos subhorizontais com contatos irregulares. Neste sentido, observa-se que as projeções em plano horizontal das duas zonas criolíticas (Fig. 10) não indicam nenhuma direção preferencial. Mesmo assim, a presença de veios inclinados e zonas de stockwork não pode ser descartada, podendo ser significativa. No topo da ZCA, na sua parte central, os corpos de criolita são horizontais a subhorizontais. Afastando-se da zona central, eles têm mergulhos de $10^{\circ}$ a $20^{\circ}$ para os 4 quadrantes configurando uma forma de cogumelo. Nas demais porções, os corpos são sub-horizontais, com extensão de até $300 \mathrm{~m}$ e possança de até $30 \mathrm{~m}$, e têm maior continuidade lateral na base da ZCA e no topo da ZCB. A maior concentração de corpos situa-se parte mediana da Zona B.

As formas das zonas criolíticas obtidas pelo modelamento (Fig. 11) correspondem à forma que envelopa o minério economicamente explorável. Nos diversos perfis efetuados, a ZCA é a mais irregular, tanto lateralmente como verticalmente. No $\mathrm{AGN}$, os teores de $\mathrm{Sn}, \mathrm{Nb}$, Ta decrescem de forma linear com a profundidade. O teor de corte do Sn, por exemplo, é de $0,1 \%$, situando-se, em média, na cota $(+) 50 \mathrm{~m}$. No entorno do DCM, as curvas de isoteor do $\mathrm{Sn}$ permanecem sub-horizontais (Figura 11B). Entretanto, as curvas do $\mathrm{Nb}$ (Fig. 11A), acompanhadas pelo Ta (Fig. 11C), aprofundam-se de forma muito destacada na região do $\mathrm{DCM}$, onde a curva de $0,1 \%$ do $\mathrm{Nb}$ situa-se na cota (-)100 m (porção mediana da ZCB). No conjunto de perfis, constata-se a existência de enriquecimentos localizados de $\mathrm{Nb}$ $\mathrm{e} \mathrm{Ta}$ em meio às zonas criolíticas e uma tendência de maiores concentrações de Nb ocorrerem na parte NE do DCM. As zonas criolíticas não exercem influência nos teores do $\mathrm{U} \mathrm{e} T h$.

A maior parte da ZCA encontra-se encaixada no AGN. Na sua parte inferior, ocorrem intercalações do granito hipersolvus albitizado, na forma de lentes interdigitadas, com espessuras que variam entre $5 \mathrm{~m}$ a $10 \mathrm{~m}$, acompanhando a base da ZCA e o topo da ZCB. Neste local, o contato entre o GH e AGN é marcado pela ocorrência de fenocristais de feldspato alcalino do GH no AGN, constituindo prováveis relictos do primeiro no segundo. Observa-se albitização no $\mathrm{GH}$ e, em alguns casos, o contato entre os granitos é marcado por concentrações elevadas de criolita e zircão. No AGN intercalado nas zonas crioliticas, a albita en échiquier é mais abundante e configura-se uma zonação vertical marcada pelo enriquecimento e maior desenvolvimento deste mineral em profundidade. Também ocorrem maiom res concentrações de criolita disseminada (Figura 12A e 12B), atingindo até $50 \%$ do volume. A criolita disseminada é do tipo caramelo (ver abaixo), em cristais de dimensões entre 0,15 a 1,0 $\mathrm{mm}$, em geral interdigitados com as micas. O GH que ocorre na base do DCM delimita o depósito, onde criolita, zircão, pirocloro e cassiterita tornam-se esparsos a ausentes. Neste local, o GH encontra-se intensamente alterado por processos hidrotermais, ocorrendo concentrações de mica branca e fluorita.

No topo e laterais do DCM ocorre uma "auréola pegmatóide" (Costi 2000) que é pouco desenvolvida ou inexistente na base. A auréola tem espessura de $0,5 \mathrm{~m}$ até $30 \mathrm{~m}$ e localmente interdigita-se com os corpos de criolita. É constituída por lentes irregulares a amendoadas de feldspato alcalino mesopertítico associado a quartzo leitoso e hialino (Fig. 12C, D, E) e, em menor proporção, por concentrações maciças de micas escuras, por criolita, galena e xenotima, sendo estes dois últimos de ocorrência mais localizada. No presente estudo, constatou-se que a galena e uma parte da criolita ocorrem em veios discordantes da auréola e que esta pode ser anterior ao DCM.

$O$ contato entre os corpos de criolita e a rocha encaixante ocorre de três formas. Pode ser marcado por uma auréola de mica branca e zircão (Fig. 12F) com espessura de até $3 \mathrm{~cm}$, localmente com forte oxidação da encaixante. Pode ser marca- do por concentrações de biotita, criolita e zircão disseminados na encaixante (Fig. 12G). Ou pode ser uma linha de contato definida com protuberâncias da criolita maciça na encaixante. Em lâmina petrográfica, são nítidas as feições de corrosão do quartzo e feldspato (mais notadamente a albita en échiquier) da encaixante pela criolita da borda do veio maciço.

A criolita dos corpos maciços pode ser de três tipos (índices de cores em itálico). $O$ índice de cores segue a classificação de Goddard et al. 1975. A criolita nucleada (Fig. 12I, 12J) tem a borda variando do marrom amarelado escuro (10 YR 4/2) ao marrom escuro (5YR 2/2) e o núcleo cinza claro médio $(N 6)$, tipicamente forma os cristais mais euédricos e mais desenvolvidos dos veios. A criolita caramelo (Fig. 12F, 12H), com cores do marrom amarelado escuro (10 YR 4/2) ao marrom escuro (5YR $2 / 2$ ), ocorre formando uma massa maciça que englobando os cristais de criolita nucleada. A criolita branca (Fig. 12K) tem uma cor cinza muito claro $(N 8)$ e pode ser muito translúcida, mais freqüentemente, é composta por aglomerados de indivíduos finos, bem cristalizados, adquirindo um aspecto sacaroidal, localmente pode ser maciça, por vezes ocorrem feições que se assemelham a linhas de crescimento conferindo um aspecto incipientemente bandado.

Na parte superior do DCM, ocorre criolita caramelo e, subordinadamente, criolita nucleada. Nos corpos intermediários, criolita caramelo (aqui mais clara) e criolita nucleada ocorrem em iguais proporções. $\mathrm{Na}$ parte inferior, a criolita nucleada é predominante, a criolita caramelo é ainda mais clara e, somente aqui, ocorre a criolita branca. $\mathrm{Na}$ base da $\mathrm{ZCB}$ ocorrem alguns corpos constituídos aparentemente só por criolita branca, com possança de até $2,20 \mathrm{~m}$. Em alguns destes corpos ocorre fluorita associada (Fig. 11L) e a encaixante é fortemente alterada.

OBSERVAÇÕES PETROGRÁFICAS O contato entre a criolita dos corpos maciços e a encaixante é caracterizado por feições de corrosão (Fig. 13A). Os corpos são essencialmente constituídos por criolita $(\sim 87 \%$ p. vol.) em cristais de até 15 $\mathrm{mm}$ de diâmetro, geralmente maclados. Predomina a geminação polissintética (Fig. 13C). Em alguns cristais, o maclamento ocorre segundo uma direção preferencial e 2 direções oblíquas relacionadas à primeira (Fig. 13D). Em outros casos, um mesmo cristal pode mostrar duas direções de maclamento independentes (Fig. 13E) ou um maclamento aparentemente mais antigo superposto por outro que parece relacionado a fraturamento (Fig. 13F). Fragmentos de cristais de criolita com finas maclas e diâmetro de até $0,52 \mathrm{~mm}$ ocorrem inclusos em cristais maiores. Localmente, no contato entre os grãos, observa-se material microcristalino tentativamente identificado como mica. Maclas de aspecto romboédrico ocorrem mais freqüentemente em cristais menores $(0,15 \mathrm{~mm}$ a $0,37 \mathrm{~mm})$. Cristais maiores de criolita, em contato com cristais menores, podem apresentar fraturas paralelas aos seus limites. Em fraturas que cortam a criolita, ocorrem zonas de alteração com minerais tentativamente identificados como thonsenolita e prosopita.

Os demais minerais constituem em conjunto $\sim 13 \% \mathrm{p}$. vol dos corpos. São principalmente quartzo, zircão e feldspato distribuídos por toda a extensão vertical do DCM, todos com dimensões em geral $<0,15 \mathrm{~mm}$, contrastando com a criolita. O zircão, idiomórfico e límpido, é idêntico ao zircão tardio do AGN. A gagarinita (Fig. 13E, G, H) (fluoreto de Y e ETR) ocorre desde a porção mediana até a base da ZCA (onde é mais abundante), como cristais $(0,4 \mathrm{~mm}$ a $1,7 \mathrm{~mm}$ ) inclusos ou cortados pela criolita. Apresenta exsolução de uma fase mineral com composição de fluocerita (Pires 2005) que também é cortada pela criolita. A fluorita, de cor amarela e violácea, ocorre na borda dos corpos de criolita branca ocupando espaços intersticiais às micas, preenchendo fraturas que cortam a criolita ou substituindo este 


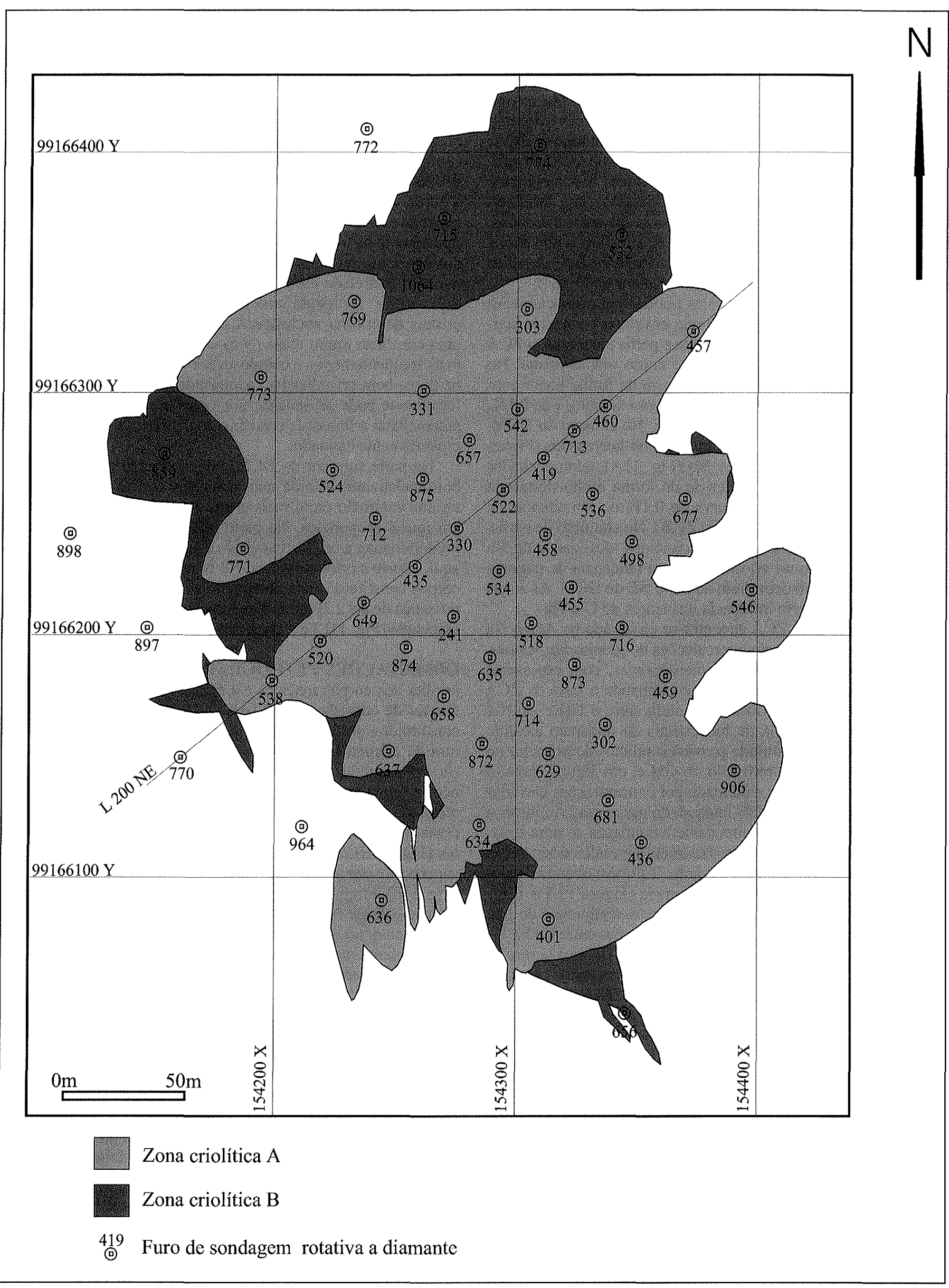

Figura 10: Projeção do depósito criolítico maciço em superficie, obtida pelo modelamento geológico com software GEMCOM 4.11, com a localização da malha de sondagem rotativa. 
mineral com formação de textura em cárie (Fig. 13B).

DISCUSSÕES Segundo Costi (2000), o albita granito é sobrejacente ao granito hipersolvus e o conjunto representa uma intrusão lateral, em forma de folha, ligada a abatimento de caldeira, repousando sobre rochas vulcânicas do Grupo Iricoumé. Esta interpretação limita a continuidade do depósito polimetálico em profundidade. $O$ mapeamento geológico e os novos furos de sondagem da porção sul do albita granito evidenciam o mergulho centrifugo das lentes de greisens, a continuidade das subfácies AGN e AGB em profundidade e a inexistência de continuidade entre o granito hipersolvus sob o DCM e o afloramento desta fá- cies na parte sudoeste da mina. Configura-se para o albita granito uma forma dômica e a localização da mineralização primaria disseminada na zona apical do mesmo. O limite inferior da mineralização é caracterizado por uma diminuição gradual dos teores e não por uma descontinuidade litológica/estratigráfica.

A forma geral do DCM assemelha-se a um cogumelo lenticular instalado ao longo do eixo central vertical do albita granito em pelo menos dois níveis (a Zona Criolítica Zero seria um terceiro nível). Outras evidências mostram que este eixo foi um caminho preferencial para os fluidos desde a consolidação do AGN. A primeira é a zonação vertical marcada pelo enriquecimento em albita en échiquier no AGN intercalado nas zonas

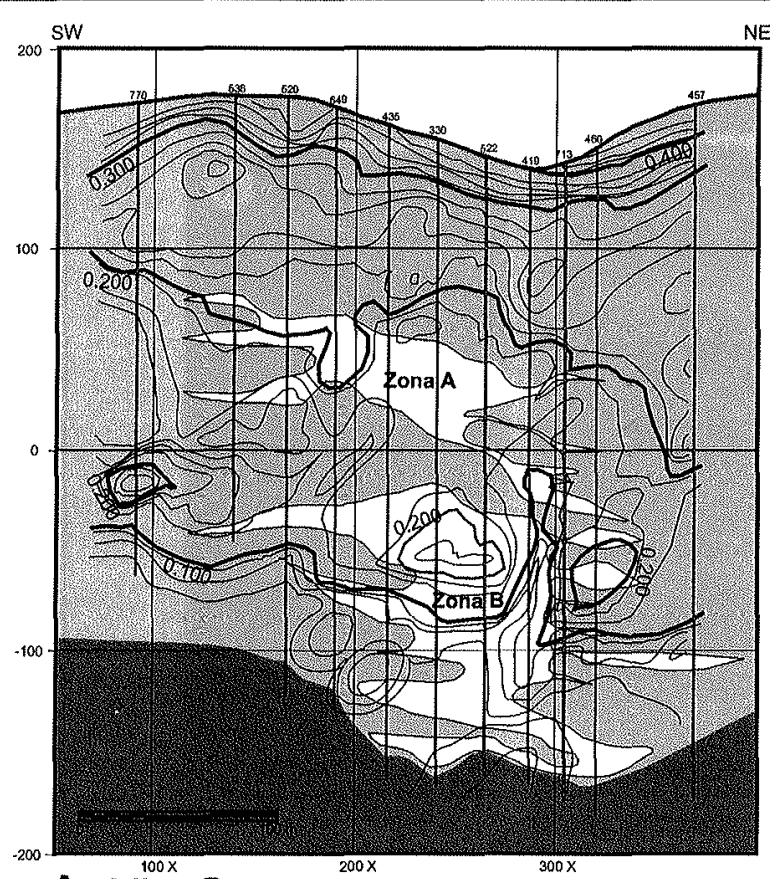

A $\mathrm{Nb}_{2} \mathrm{O}_{5}$

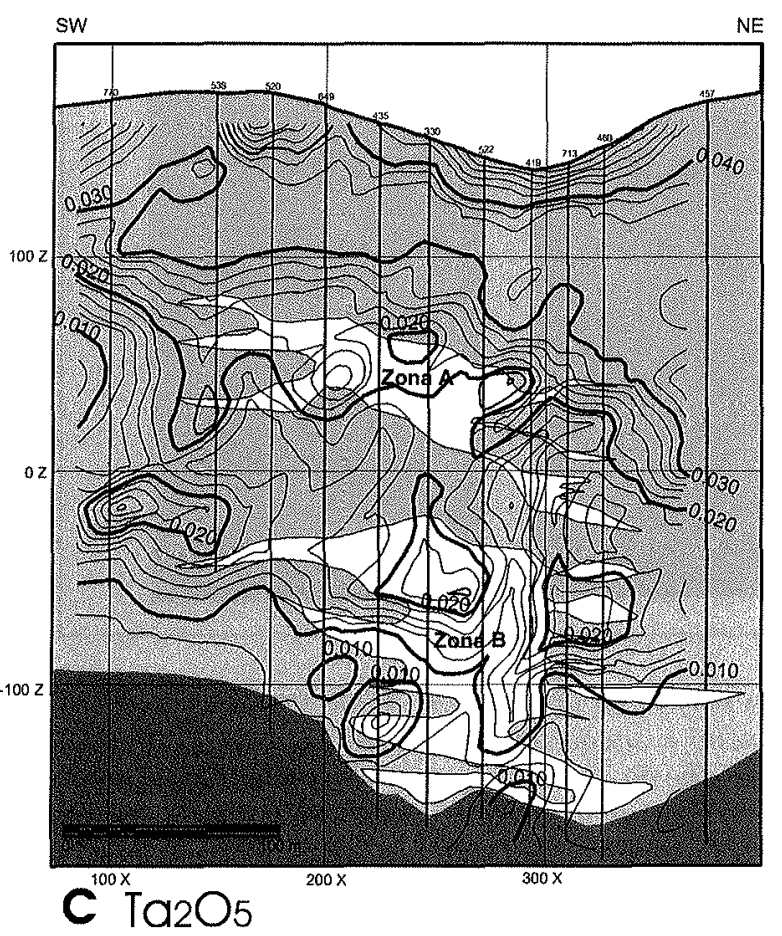

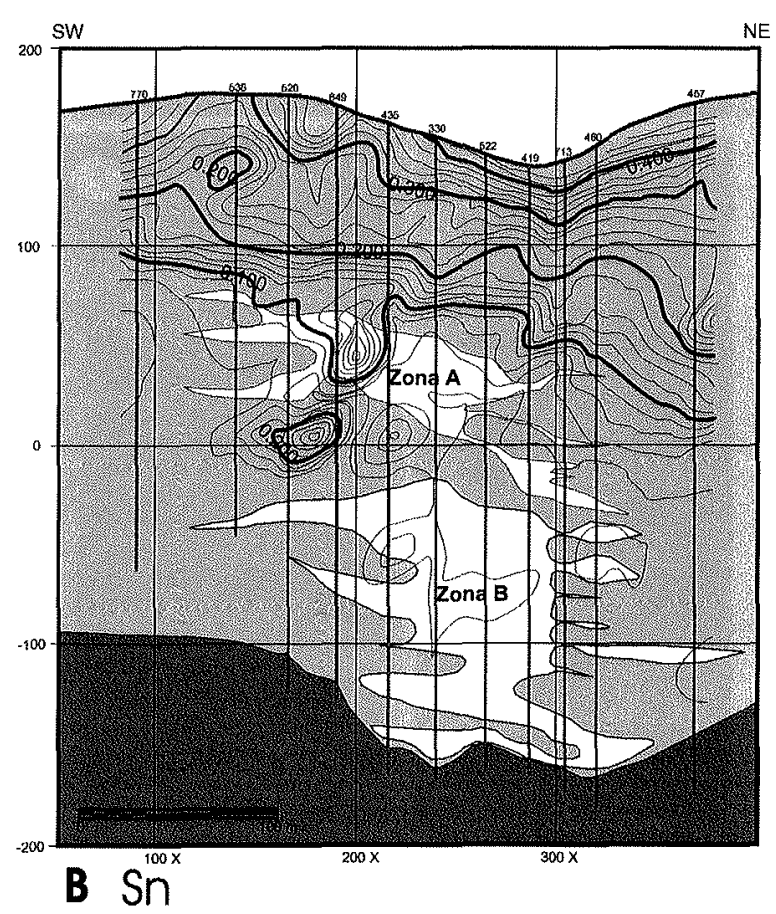

NE

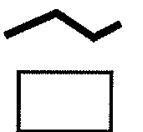

0.040 Curva de isoteor $(\%)$

Zona criolítica

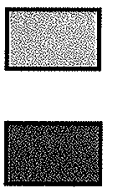

522
Albita granito de núcleo

Granito hipersolvus com

intercalações de granito albitizado

Furo de sondagem

Figura 11: Modelagem geológica do Depósito Criolítico Maciço (Perfil L200NE, vide Figura 10) pelo software GEMCOM 4.11, com curvas de isoteores de $\mathrm{Sn}, \mathrm{Nb2O5}$ e Ta2O5. 


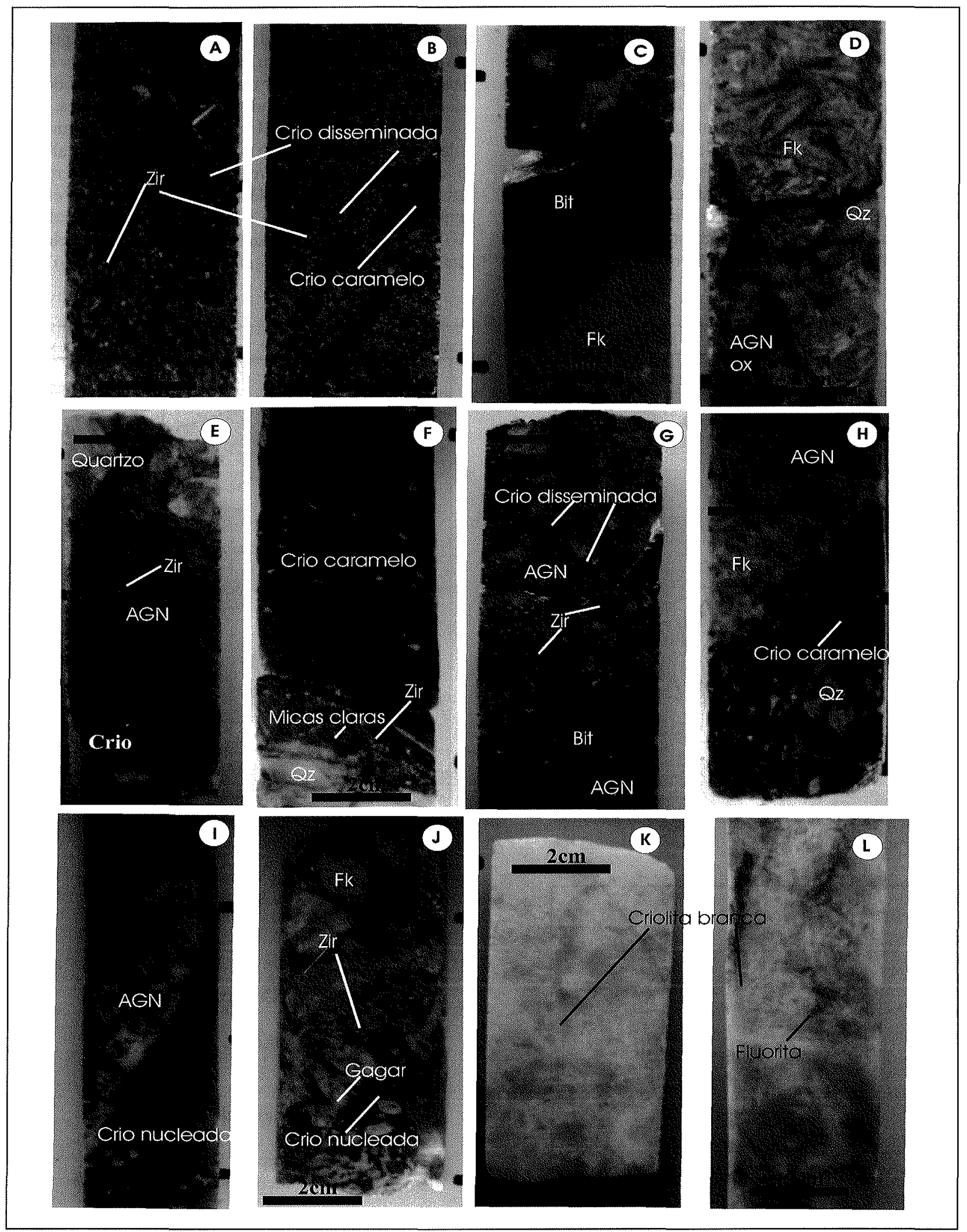

Figura 12: Fotografias de testemunhos do albita granito de núcleo e dos corpos de criolita: (A) Albita granito no contato com corpo de criolita com alta concentração de criolita disseminada (caramelo) e zircão (cinza); (B) Albita granito apresentando concentrações de criolita disseminda e lentes de criolita caramelo; (C): Detalhe da auréola pegmatóide com feldspato potássico e mica; (D): Auréola pegmatóide com feldspato potássico, quartzo em contato com albita granito oxidado; (E): Auréola pegmatóide com criolita, quartzo e alta concentração de zircão; $(F)$ : Contato da auréola pegamtóide (mica branca e quartzo leitoso) com o corpo de criolita caramelo; $(G)$ : Contato irregular entre o albita granito e o corpo de criolita, com lentes de biotita paralelas ao contato; (H): Contato tríplice entre albita granito, auréola pegmatóide (feldspato potássico) e corpo criolítico (criolita caramelo e quartzo); (I). Corpo de criolita nucleada com relicto do albita granito; (J): Criolita nucleada com inclusões de gagarinita e zircão; (K): Corpo de criolita branca e caramelo subordinada; (L): Criolita branca com fluorita associada. Abreviaturas: (crio) criolita; (gagar) gagarinita; (zir) zircão; (Fk) feldspato alcalino; (bi) biotita; (qz) quartzo; (AGN) albita granito de núcleo; (ox) oxidado. 

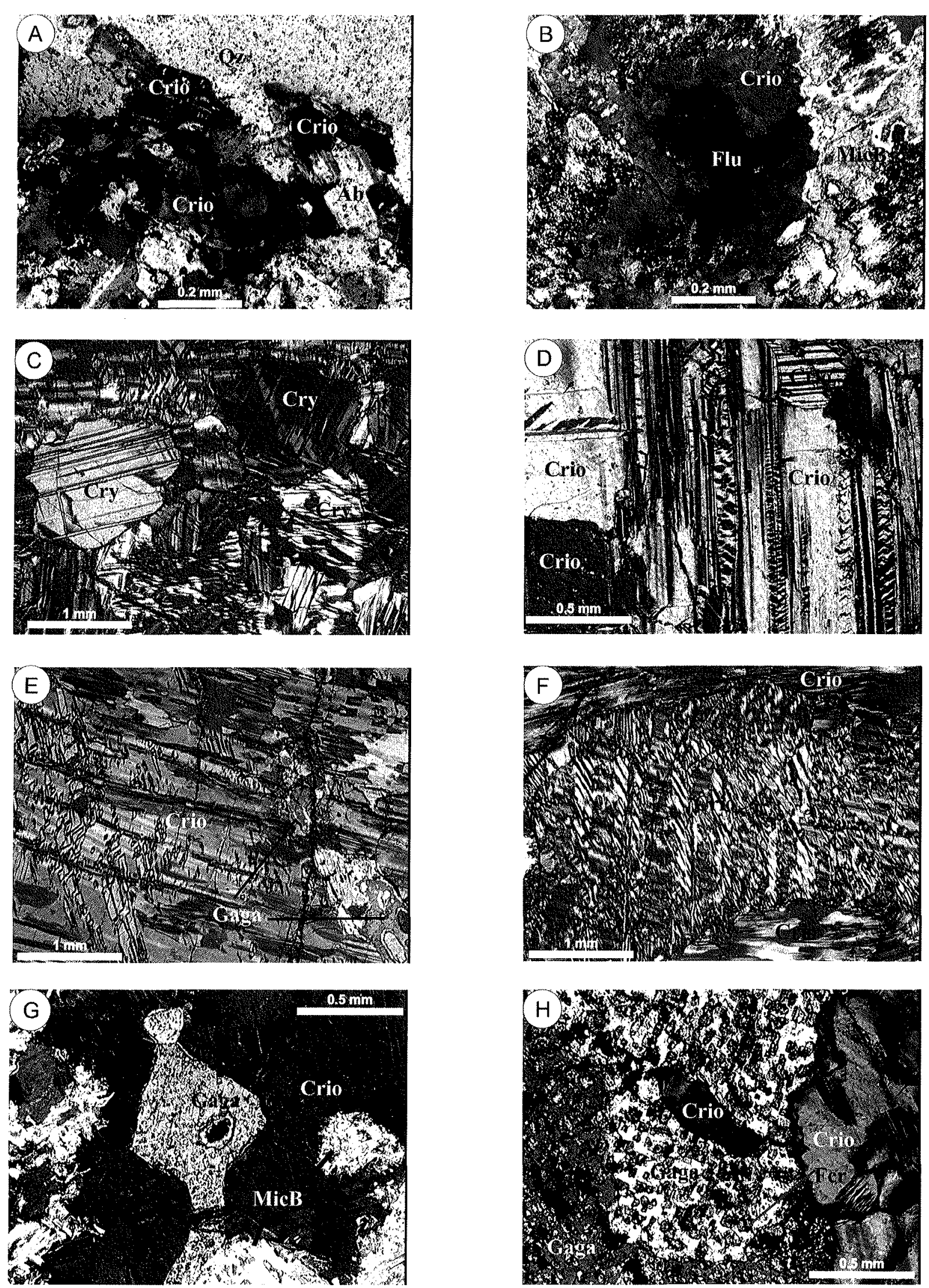

Figura 13: Fotomicrografias. (A) Criolita disseminada no albita granito no contato com o corpo de criolita com feições de corrosão do quartzo e albita da rocha; (B) Fluorita substituindo a criolita em textura tipo cárie; (C) Corpo de criolita formada por cristais maclados; (D) Corpo de criolita formada por cristais de maclamento complexo; (E) Cristal de criolita com duas direções de maclamento independentes, com inclusão de gagarinita; $(F)$ Cristal de criolita maclada afetado por fraturamento; $(G)$ Cristal de criolita envolvendo cristal de gagarinita; (H) Cristais de gagarinita com exsolução de fluocerita (?). Abreviaturas: ( $Q z)$ quartzo, (Zr) zircão, (MicB) mica branca, (Ab) albita, (Crio) criolita, (Gaga) gagarinita, (Fcr) Fluocerita, (Flu) fluorita. 
W
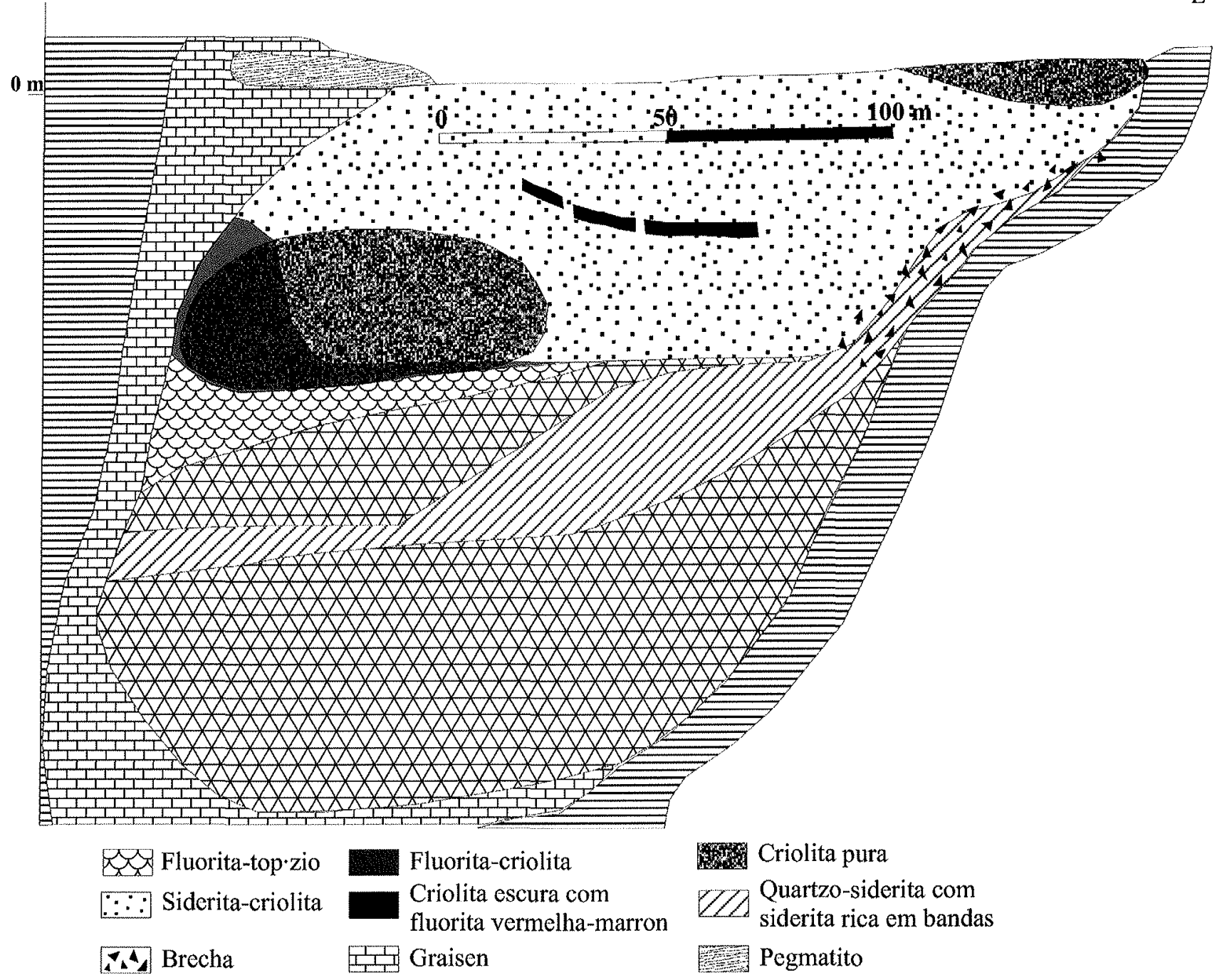

Criolita pur

Quartzo-siderita com

Pegmatito

Granito

Figura 14: Perfil longitudinal do depósito criolítico de Ivigtut, Pauly \& Bailey (1999).

Figura 14: Perfil longitudinal do depósito criolitico de Ivigtut, Pauly \& Bailey (1999).

criolíticas. A segunda é a distribuição das curvas de isoteores de $\mathrm{Nb}$ e Ta aprofundando-se na zona do DCM. A columbitização do pirocloro relacionada ao fluido formador do DCM (Minuzzi 2004) implica o enriquecimento de $\mathrm{Nb}$ e Ta na fase mineral neoformada em relação ao mineral original, mas não explica o enriquecimento na rocha que, conseqüentemente, foi anterior à formação do DCM. A terceira refere-se à localização abundante de fases pegmatóides ao longo deste eixo, representadas pela "auréola pegmatóide".

O controle da migração de fluidos acima referido pode ter sido em parte tectônico, entretanto o conjunto de evidências neste sentido é precário e em parte contraditório. $\mathrm{O}$ alongamento do albita granito na direção N-S contrastando com a orientação NESW do granito Madeira sugere a intervenção de uma estrutura $\mathrm{N}-\mathrm{S}$. Entretanto, as curvas de isoteores de $\mathrm{Nb}$ e Ta indicam um enriquecimento nestes elementos no sentido NE-SW. Segundo Pauly (1978), as maclas da criolita de Ivigtut são oriundas de efeitos mecânicos, indicando diferentes estágios de reorientação em resposta a situações de tensão de tectônica rúptil. Em
Pitinga, a criolita maciça é maclada, entretanto as Zonas Criolíticas A e B (Figura 10) não têm nenhuma direção preferencial que possa ser relacionada a uma tectônica rúptil ativa durante a formação do depósito. Por outro lado, não se observa, na rocha encaixante, estruturas ou variações litológicas horizontais a subhorizontais que possam ter controlado a disposição semelhante dos corpos de criolita maciça.

A paragênese magmática é caracterizada por inversões na seqüência de cristalização normalmente esperada, sendo exemplos, entre outros, a cristalização precoce do quartzo e as cristalizações tardias do zircão e riebeckita. O presente trabalho confirma as existências de criolita disseminada precoce e tardia (Costi 2000), corroborando, portanto, a idéia de um magma excepcionalmente rico em $\mathrm{F}$, o que explica a evolução particular da paragenênese, conforme já discutido do ponto de vista petrológico por Lenharo (1998) e Costi (2000).

Entre as zonas criolíticas (ZCA e ZCB), identificou-se lentes de GH interdigitado ao AGN. O contato entre o GH e AGN é marcado pela ocorrência de fenocristais de feldspato alcalino 
W

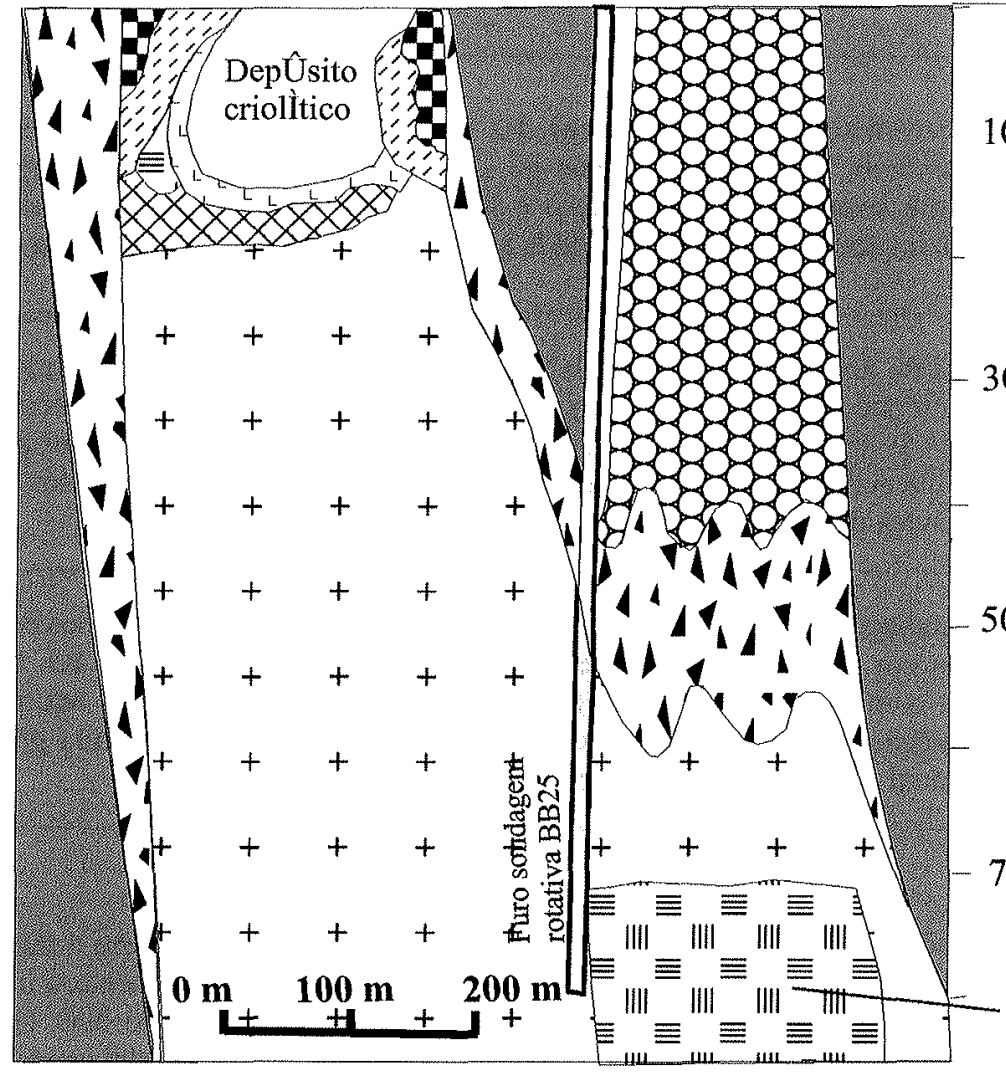

E Nìvel

do mar

$100 \mathrm{~m}$

$300 \mathrm{~m}$

$500 \mathrm{~m}$

$700 \mathrm{~m}$

¿rea de criolita

disseminada

no granito

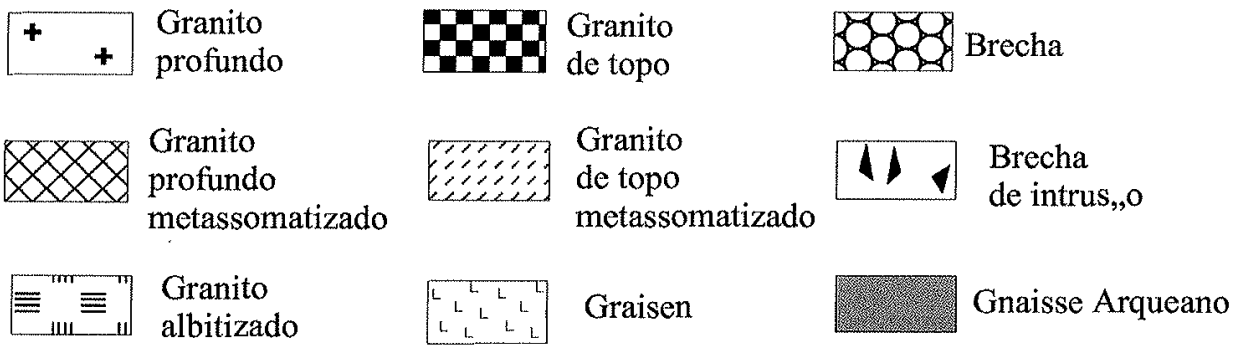

Figura 15: Perfil do stock granitico de Ivigtut e do depósito criolitico segundo Karup-Moller e Pauly (1979), Bailey (1980) e Bon$\operatorname{dam}(1991)$.

do GH no AGN, constituindo prováveis relictos do primeiro no segundo. Da mesma forma, em escala de depósito, foram identificados corpos de GH dentro do AGN. Feições texturais identificadas no GH albitizado e no AGN, tais como aglomerados de quartzo e feldspato alcalino com contatos retos, indicam equilíbrio entre ambos, sendo envolvidos pela massa albítica em nítido desequilíbrio com os fenocristais. Estas evidências sugerem a transformação do $\mathrm{GH}$ em uma rocha do tipo AGN por processo de albitização relacionado à atuação de fluidos tardios pós-magmáticos sobre os feldspatos em estágio subsolidus (Smith \& Brown 1988). As descrições petrográficas revelam um volume significativo de albita ${ }^{a}$ échiquier na porção ocupada pelo $\mathrm{DCM}$, especialmente na ZCB, a mais importante, sugerindo uma relação entre a albitização e a formação do DCM.

Outra associação mineral típica da zona do DCM é a auréola pegmatóide. Segundo Costi (2000), a auréola interdigita-se com os corpos de criolita maciça, o que levaria a supor uma formação síncrone. Os novos dados petrográficos indicam que a formação da auréola é anterior ao DCM. A gagarinita, cortada pela criolita e afetada por exsoluções também anteriores à criolita, representa um dos minerais típicos da fase pegmatóide. Trata-se de um mineral raro e que, no caso de Pitinga, é excepcionalmente rico em ETR (Pires 2005), elementos comumente enriquecidos em pegmatitos. Gagarinita de composição semelhante foi descrita apenas em granitos albitizados, associada a veios/bolsões de quartzo e feldspato potássico. Possivelmente, assim como a gagarinita, parte dos feldspatos e quartzo encontrados nos corpos de criolita maciça representam relictos da fase pegmatóide.

Algumas das características principais do depósito de Ivigtut são apresentadas nas figuras 14 e 15 . O modelo genético magmático desenvolvido por Pauly e colaboradores baseia-se na refusão de uma parte do granito muito rica em $\mathrm{F}$, originando um corpo de proto-minério que evoluiu segregando-se em diferentes unidades (Fig. 15), o que ocorreu em parte devido a uma série de abatimentos. Este modelo mostrou-se frágil diante de dados isotópicos (Blaxland 1976; Goodenough et al. 2000) que 
Tabela 3. Enquadramento da mineralização de criolita nos esquemas evolutivos propostos para o albita granito.

\begin{tabular}{|c|c|}
\hline Modelo & Evidências \\
\hline $\begin{array}{l}\text { Modelo metassomático } \\
\text { Horbe et al. }(1985,1991) \\
\text { Teixeira et al., }(1992)\end{array}$ & $\begin{array}{l}\text { Transformações metassomáticas das fases ígneas precedentes. Teores elevados teores de } \mathrm{F} \\
\text { rebaixaram o limite do solidus do sistema. Cristalização dos apogranitos no intervalo do } \\
\text { estágio pneumatolítico (núcleo) e hidrotermal (borda). Presença de criolita em lugar do } \\
\text { topázio, como fase portadora de F, sugere uma origem metassomática dos apogranitos. }\end{array}$ \\
\hline $\begin{array}{l}\text { Modelo magmático } \\
\text { (por imiscibilidade) } \\
\text { Lenharo (1998) }\end{array}$ & $\begin{array}{l}\text { O albita granito cristalizou sob condições oxidantes (série magnetita) e não é quimicamente } \\
\text { relacionado às outras fácies dos maciços Água Boa e Madeira por processos de fracionamento, } \\
\text { tendo se originado de uma fonte completamente distinta. A origem dos corpos maciços de } \\
\text { criolita seria relacionada à formação de fusões imiscíveis de fluoretos durante a cristalização } \\
\text { da fácies de núcleo. }\end{array}$ \\
\hline $\begin{array}{l}\text { Modelo magmático } \\
\text { (fase residual) } \\
\text { Costi }(2000)\end{array}$ & $\begin{array}{l}\text { Cristalização do albita granito a partir de líquidos residuais derivados de magmas inicialmente } \\
\text { ricos em } \mathrm{F} \text { e empobrecidos em } \mathrm{MgO}, \mathrm{TiO}_{2} \text { e principalmente } \mathrm{CaO} \text {. O aumento do teor de } \\
\mathrm{H}_{2} \mathrm{O} \text { com o avanço da cristalização leva à separação de fluidos aquosos, responsáveis pela } \\
\text { formação das rochas dos níveis pegmatíticos no interior do albita granito, enquanto a fase } \\
\text { residual rica em } \mathrm{F} \text { geraria os corpos de criolita maciça }\end{array}$ \\
\hline
\end{tabular}

descartam qualquer tipo de vínculo entre o granito encaixante e o fluido mineralizador. Este seria um fluido carbonatítico, rico em $\mathrm{F}$, originado no manto, praticamente sem contaminação crustal, que, por suas baixas densidade e viscosidade, atravessou rapidamente o corpo granítico até seu trapeamento na parte superior da intrusão. Os modelos genéticos em discussão para mineralização de criolita de Pitinga são sintetizados na Tabela 3.

Em Ivigtut, as composições química e mineralógica do depósito são contrastantes com as da encaixante. Em Pitinga, os corpos de criolita maciça não representam um corpo exótico no albita granito, tendo total afinidade com a paragênese do mesmo. Um modelo metassomático como o de Ivigtut, onde rocha e minério têm origens completamente desvinculadas é inaplicável em Pitinga.

Em Pitinga, a relação de contato entre os corpos de criolita e a encaixante é tipicamente reativa. A mineralização criolítica promoveu a dissolução de significativo volume do AGN, com conseqüente preenchimento das cavidades, assim geradas, pela massa criolítica. Caracterizam-se condições de P e T bastante distintas e, provavelmente, um hiato temporal significativo - para as formações da encaixante e do minério, respectivamente. A formação dos corpos maciços dificilmente poderia ser atribuída aos estágios magmático (Lenharo 1999) ou pegmatítico (Costi 2000). Nestes modelos, o líquido formador dos corpos maciços teria alta fluidez, não sendo possível explicar serem os corpos maciços localizados apenas no eixo central vertical do albita granito, enquanto que outras zonas pegmatóides (sem criolita maciça) distribuem-se por todo o AGN. A formação dos corpos de criolita maciça é mais compatível com o estágio hidrotermal. Pelas relações texturais, o preenchimento das cavidades iniciou-se pela criolita nucleada (cristais zonados, euédricos a subédricos, sugerindo a cristalização precoce e em espaço livre), seguida pela criolita caramelo (aspecto maciço, espacialmente distribuída envolvendo a criolita nucleada) e, finalmente, pela criolita branca (reflexo provável do empobrecimento da solução mineralizante, culminando em cristais incolores de caráter tardio).

CONSIDERAÇÕES FINAIS O albita granito é uma rocha com textura magmática e composição mineralógica de um pegmatito que intrudiu as demais fácies do Granito Madeira formando um domo em cuja parte apical ocorre o minério disseminado de $\mathrm{Sn}$, $\mathrm{Nb}$, Ta, criolita e Zr. Possivelmente, a intrusão foi controlada por uma estrutura rúptil de direção N-S. Os processos previamente ocorridos na zona do DCM, albitização e formação da "auréola pegmatóide", atestam que esta zona foi, desde a consolidação do albita granito, um caminho preferencial para a circulação de fluidos que poderia estar relacionado a uma reativação da estrutura referida. As modificações na paragênese do albita granito ligadas a estes processos criaram um local preferencial, do ponto de vista mineralógico, para formação do DCM.

A formação dos corpos de criolita maciça enquadra-se num modelo genético hidrotermal, no qual fluidos de baixa temperatura teriam desestabilizado minerais formados em estágios anteriores a temperaturas mais altas, gerando os espaços para deposição de criolita hidrotermal. Este circuito hidrotermal teria envolvido essencialmente fluidos de origem magmática, residuais do próprio albita granito, ascendentes das partes mais inferiores deste corpo. No entorno do DCM, estes fluidos promoveram enriquecimentos no minério disseminado, através da columbitização do pirocloro (Minuzzi 2004) e da formação de criolita e zircão hidrotermais. Subseqüentemente, as soluções podem ter sido gradualmente diluídas e resfriadas pelo aporte de fluidos meteóricos, ocorrendo, talvez neste estágio, a deposição da criolita tardia branca. $\mathrm{Na}$ continuidade do processo, ocorre a deposição de fluorita - onde a presença de Ca registra, provavelmente, o aporte de fluidos das rochas encaixantes do albita granito - e os processos de formação de minerais secundários afetando a própria criolita do DCM.

As duas únicas jazidas de criolita existentes no mundo são muito diferentes em todos os sentidos. Em Ivigtut, o minério representa um corpo totalmente exótico em relação à sua encaixante, corroborando os dados geoquímicos que apontam para um modelo metassomático no sentido mais extremo, onde os fluidos responsáveis pela mineralização não têm nenhuma ligação com a encaixante do depósito ou sequer com outras rochas da região. Em Pitinga, o depósito criolítico maciço enquadra-se perfeitamente, no que tange aos aspectos básicos aqui tratados, no que seriam as características esperadas (não há caso semelhante para comparação) para o estágio hidrotermal de uma rocha como o albita granito em questão. 


\section{Referências}

Almeida M.E., Fraga L.M.B., Macambira M.J.B. 1997. New geochronological data of calc-alcaline granitoids of Roraima State, Brazil In: South American Symposium on Isotope Geology. Abs, p. 34 35.

Almeida F.F.M., Hasui Y., Brito Neves B.B., Fuck R.A. 1981. Brazilian structural provinces: An introduction. Earth Sciences Review, 17:129.

Araújo Neto H. \& Moreira H.L. 1976. Projeto Estanho do Abonari. Relatório Final, DNPM/CPRM, Manaus, v. 2.

Bailey J.C. 1980. Formation of cryolite and other aluminofluorides: a petrologic review. Bull. Geol. Soc. Den. 29:1-45.

Bondam J. 1991. The Ivigtut Cryolite Deposit in South Greenland. Open File Ser. GGU Bol. 91:4.

Betejin A . 1977. Curso de Mineralogia. 3a Edição. Editora MIR., 725 p.

Carvalho Filho N.B., Horbe A.C., Souza P.C.B. 1984. A natureza dos depósitos de cassiterita do setor Madeira, região do Pitinga, Amazonas, Brasil. In: SBG, Symposium Amazônico, 2, Anais, p. 459 461.

Costi H.T. 2000. Petrologia de granitos alcalinos com alto Flúor mineralizados em metais raros: o exemplo do albita granito da mina Pitinga, Amazonas, Brasil. Tese de doutoramento, Centro de Geociências, Universidade Federal do Pará. Belém, $345 \mathrm{p}$.

Costi H.T., Dall'Agnol R., Moura C.A.V. 2000. Geology and Pb-Pb Geochronology of Paleoproterozoic Volcanic and Granitc rocks of Pitinga Province, Amazonian Craton, Northem Brazil. Int. Geol. Rev., 42:832-849.

Faria M.S.G., Luzardo R., Pinheiro S.S., Silva L.C. 1999. Litoquímica e petrogênese do Granito de Igarapé Azul - sudeste de Roraima. In: SBG, Simpósio de Geologia da Amazônia, 4, Boletim de Resumos, p. 577-580.

Fuck R.A., Pimentel M.M., Machado N., Daoud W.E.K. 1993. Idade $\mathrm{U}-\mathrm{Pb}$ do Granito Madeira, Pitinga (AM). In: SBG, Congresso Brasileiro de Geoquímica, 4, Bol. Res. Exp., p. 246-249.

GEMCOM do Brasil LTDA. Software GEMCOM 4.11.Gibbs A. K.\& Barron C.N. 1983. The Guiana shield reviewed. Episodes, 2:7-14.

Goddard E.N., Trask P.D., Ford R.K., Rove O.N., Singewald J.T., Overbeck R.M. 1975. The Rock-Color Chart Committed. Geological Society of America, Boulder, Colorado, $8 \mathrm{p}$.

Goodenougn K.M., Upton B.G.J., Ellam R.M. 2000. Geochemical evolution of the Ivigtut granite, South Greenland: a fluorine-rich "Atype" intrusion. Lithos, 51:205-221.

Horbe M.A., Horbe A.C., Teixeira J.T., Costi H.T. 1985. Granito Madeira: petrologia, petroquímica e mineralizações. In: SBG, Simpósio de Geologia da Amazônia, 2, Anais, v. 3, p. 284-320.

Horbe M.A., Horbe A.C., Costi H.T., Teixeira J.T. 1991. Geochemical characteristics of cryolite-tin-bearing granites from the Pitinga Mine, Northwestern Brazil - A review. Journal of Geochemical Exploration, 40:227-249.

Karup-Moller S. \& Pauly H. 1979. Galena and associated ore minerals from the cryolite at Ivigtut, South Greenland. Menddeleser om Gronland, Geoscience 2:3-25.

Lenharo S.L.R. 1998. Evolução magmática e modelo metalogenético dos granitos mineralizados da região de Pitinga, Amazonas, Brasil. Tese doutoramento, Escola Politécnica da Universidade de São Paulo, $290 \mathrm{p}$

Macambira M.J.B., Teixeira J.T., Daoud W.E.K., Costi H.T. 1987. Geochemistry, mineralizations and age of tin-bearing granites from Pitinga, Northwestern Brazil. Revista Brasileira de Geociencias, 17(4):562-570.

Mineralogy Database 2005. Disponível em: http://www mineralogy database.

Minuzzi O.R.R. 1993. Relatório geológico-prospectivo Anual 1993. Grupo Paranapanema, Mineração Taboca. Mina Pitinga, Amazo- nas, $40 \mathrm{p}$

Minuzzi O.R.R. 1995. Relatório geológico-prospectivo Anual 1995 Grupo Paranapanema, Mineração Taboca. Mina Pitinga, Amazonas, $15 \mathrm{p}$.

Minuzzi O.R.R. 1992. Relatório geológico-prospectivo Anual 1992. Grupo Paranapanema, Mineração Taboca. Mina Pitinga, Amazonas, $38 \mathrm{p}$.

Minuzzi O.R.R. 2002. Modelamento geológico do Depósito Criolítico Maciço da Mina Pitinga. Grupo Paranapanema, Mineração Taboca. Mina Pitinga, Amazonas, $50 \mathrm{p}$.

Minuzzi O.R.R. 2004. A columbitização do pirocloro da subfácies albita granito de Núcleo do Granito Madeira, Pitinga-AM: relações com a gênese da mineralização criolítica. Monografia de Exame de Qualificação ao Doutorado, Instituto de Geociências, Universidade Federal do Rio Grande do Sul, $56 \mathrm{p}$.

Minuzzi O.R.R. \& Soares E.A.A. 1990. Relatório geológico-prospectivo Anual 1990. Grupo Paranapanema, Mineração Taboca. Mina Pitinga, Amazonas. 30 p.

Minuzzi O.R.R. \& Soares E.A.A. 1991. Relatório geológico-prospectivo Anual 1991. Grupo Paranapanema, Mineração Taboca. Mina Pitinga, Amazonas, $25 \mathrm{p}$.

Minuzzi O.R.R., Bastos Neto A.C., Pereira V.P.. Nunes L. 2005. A columbitização do pirocloro da subfácies albita granito de núcleo do Granito Madeira, Pitinga-AM: relações com a gênese da mineralizacão criolítica. Revista Brasileira de Geociências, no prelo.

Minuzzi O.R.R., Ferron J.T.M.M., Bastos Neto A.C., Pereira V.P. 2003. Primeira notícia da descoberta de waimirita e atroarita, dois novos minerais na Mina de Pitinga, AM, Brasil. Revista Pesquisas em Geociências, 30(1):1009-1012.

Pauly H. \& Bailey J.C. 1999. Genesis and evolution of the Ivigtut cryolite deposit, $S W$ Greenland. Medelelser om Geenland Geoscience: $37,60 \mathrm{p}$

Pennsylvania Salt Manufacturing Company 1950. Cryolite. Pennsylvania Salt Manufacturing Company, $60 \mathrm{p}$.

Pires A.C. 2005. A gagarinita e fases associadas no granito Madeira (Pitinga, Amazonas). Dissertação de Mestrado, Instituto de Geociências, Universidade Federal do Rio Grande do Sul, 122 p.

Pires J.S., Borrelli M., Ferron J.T.M.M., Salvador J.C. 1998. Relatório geoestatístico e resumo da otimização da cava de $13 \mathrm{Mt} / a n o-P r o-$ jeto Rocha Sã. Mamoré Mineração e Metalurgia Ltda. 52 p.

Santos J.O., Hartmann L.A., Gaudette H.E., Groves D.I, McNaughton N.J., Fletcher I.R. 2000. A new understanding of the provinces of the Amazon Craton based on integration of field mapping and U-Pb and Sm-Nd geochronology. Gondwana Research, 3(4):453-488.

Schobbenhaus C., Hoppe A., Lork A., Baumann A. 1994. Idade U/Pb do Magmatismo Uatumã no norte do Cráton Amazônico, Escudo das Guianas (Brasil): Primeiros Resultados. In: SBG, Congresso Brasileiro de Geologia, 38, Anais, p. 395-397.

Tassinari C.C.G. \& Macambira M.J.B. 1999. Geochronological provinces of the Amazonian Craton. Episodes, 3:174-182.

Teixeira J.T., Costi H. T., Minuzzi O.R.R., Soares E.A.A. 1992. Depósitos primários de criolita, cassiterita, xenotímio e columbita em apogranito - mina do Pitinga (AM). In: SBG, Congresso Brasileiro de Geologia, 37, Anais, 1, p. 212-213.

Teixeira J.T., Ferron J.T.M.M., Minuzzi O.R.R., Soares E.A.A. 1992 Relatório final avaliação depósito criolitico da Mina Pitinga. Mineração Taboca S. A, Ministério das Minas e Energia, DNPM, Manaus-AM.

Veiga Jr. J.P., Nunes A.C.B., Fernandes A.S., Amaral J.E., Pessoa M.R., Cruz S.A.S. 1979. Projeto Sulfetos Uatumã. Relatório Final. DNPM/CPRM, Manaus, 7 vols.

Manuscrito A-1617a

Revisão aceita em 18 de agosto de 2006 